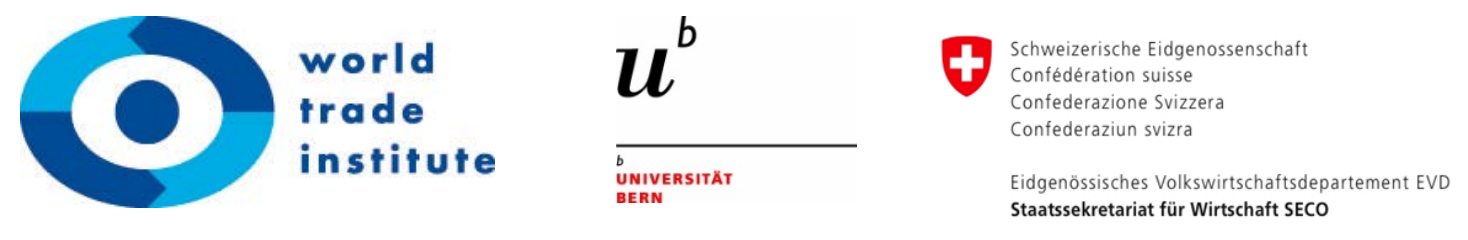

Working Paper No. 03/2017 | March 2017

\title{
Trade Impacts of the European Union - Vietnam Free Trade Agreement: The Sussex Framework Analysis
}

\author{
Ha Le \\ Foreign Trade University (FTU), Vietnam \\ halt@ftu.edu.vn
}

In February 2016, after more than three years of negotiation, the European Union and Vietnam officially announced the conclusion of negotiation and published the text of the EU-Vietnam Free Trade Agreement (EVFTA). This research focuses on the impacts of EVFTA on both economies. By using the Sussex Framework, the EVFTA is expected to have positive impacts on both economies, also exposing many opportunities and challenges to Vietnam as a developing country when trading with an economy giant of the EU. Based on the results of both quantitative and qualitative analysis, the research proposed some recommendations for Vietnamese government and enterprises to enhance the benefits of the FTA.

Research for this paper was funded by the Swiss State Secretariat for Economic Affairs under the SECO / WTI Academic Cooperation Project, based at the World Trade Institute of the University of Bern, Switzerland.

SECO working papers are preliminary documents posted on the WTI website (WWW.Wti.org) and widely circulated to stimulate discussion and critical comment. These papers have not been formally edited. Citations should refer to a "SECO / WTI Academic Cooperation Project" paper with appropriate reference made to the author(s). 


\section{TABLE OF CONTENTS}

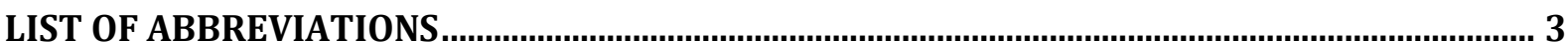

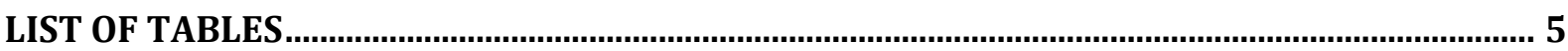

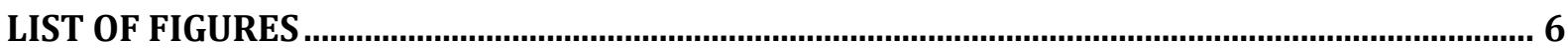

FIGURE 1-1: VIETNAM'S EXPORTS AND IMPORTS TO AND FROM THE EU (2005 TO 2014). 6

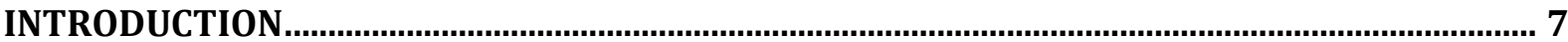

CHAPTER 1: BACKGROUND ON THE EU - VIETNAM RELATIONSHIP ....................................... 9

1.1. DiPLOMATIC RELATIONS BETWEEN THE EU AND VIETNAM ................................................................ 9

1.2. THE EU - VIETNAM TRADE RELATIONS..............................................................................................

1.3. THE EU - VIETNAM FTA AND ITS ROLES IN THE REGION ………………………............................ 11

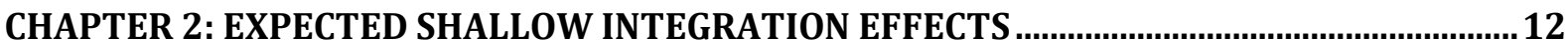

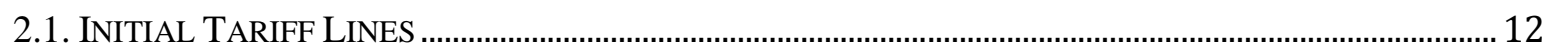

2.2. NUMBER OF PARTNERS INVOLVED IN THE FTA.......................................................................... 15

3.4. REVEAL COMPARATIVE ADVANTAGE (RCA) …............................................................................ 20

2.5. SIMILARITY OF PRODUCT MIXES IN THE TWO ECONOMIES ............................................................... 24

2.6. CONCLUSION ON SHALLOW INTEGRATION …………........................................................................ 25

CHAPTER 3: EXPECTED DEEP INTEGRATION EFFECTS

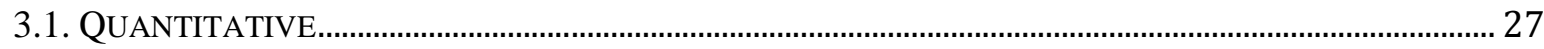

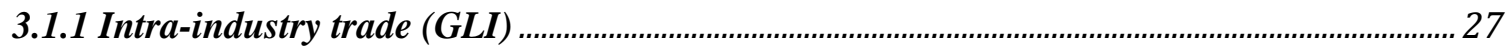

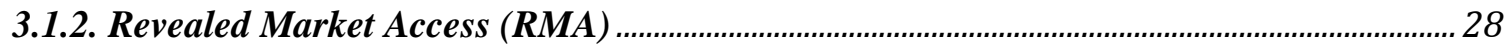

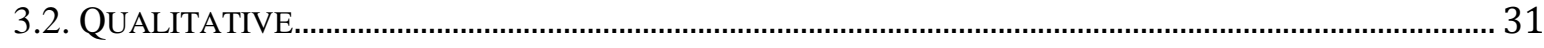

3.2.1. Foreign Direct Investment \& Trade in Services........................................................................... 31

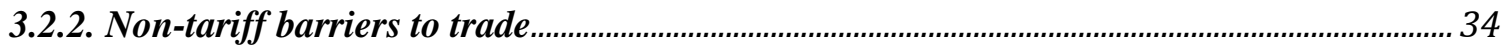

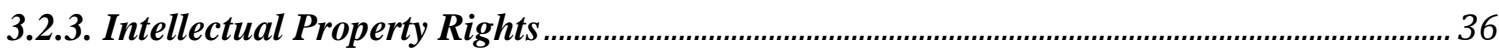

CHAPTER 4: OPPORTUNITIES, CHALLENGES AND RECOMMENDATIONS FOR VIETNAM ....43

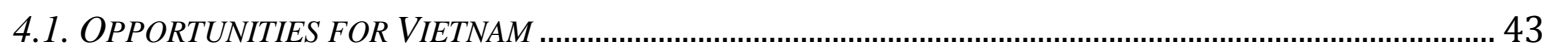

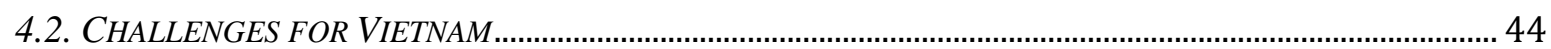

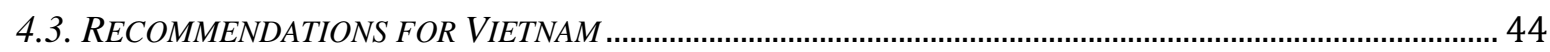

CONCLUSIONS

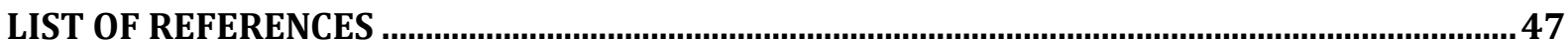




\section{LIST OF ABBREVIATIONS}

ASEAN

CARIS

CBD

CITES

DAGs

EU

EVN

EVFTA

FCA

FDI

FKI

FRRI

FTA

GDP

GLI

GPA

GSP

HS

IIT

ILO

IPRs

NTBs

NTMs

OECD

PCA

RCA

RMA

RT

SDR

SEA

SF

SMEs

SPS
Association of Southeast Asian Nations

Centre for the Analysis of Regional Integration at Sussex

Convention on Biological Diversity

Convention on International Trade in Endangered Species

Domestic Advisory Groups

European Union

Electricity of Vietnam

European Union - Vietnam Free Trade Agreement

Framework Cooperation Agreement

Foreign Direct Investment

Finger-Kreinin Index

Foreign Direct Investment Regulatory Restrictiveness Index

Free Trade Agreement

Gross Domestic Product

Gruber-Lloyd Index

Government Procurement Agreement

Generalised Scheme of Preferences

Harmonized System

Intra-Industry Trade

International Labour Organization

Intellectual Property Rights

Non-Tariff Barriers

Non-Tariff Measures

Organisation for Economic Co-operation and Development

Partnership and Cooperation Agreement

Revealed Comparative Advantage

Revealed Market Access

Rule of Thumb

Special Drawing Rights

Southeast Asia

Sussex Framework

Small and Medium-sized Enterprises

Sanitary and Phytosanitary Measures 
TBT

TCI

TPP

TRAINS

TRIPS

TTIP

UK

UNFCCC

USD

USTR

VNR

WIPO

WITS

WTO
Technical Barriers to Trade

Trade Concentration Index

Trans-Pacific Partnership

Trade Analysis Information System

Agreement on Trade-Related Aspects of Intellectual Property Rights

Transatlantic Trade and Investment Partnership

United Kingdom

United Nations Framework Convention on Climate Change

United States Dollars

United States Trade Representative

Vietnam Railway

World Intellectual Property Organization

World Integrated Trade Solution

World Trade Organization 


\section{LIST OF TABLES}

Table 2-2: Comparative bilateral tariff profiles of the EU and Vietnam (2004-2014)

Table 2-9: Vietnam's top exports to the EU and corresponding imports (2005-2014, HS-1996 2-digit level)

Table 2-10: The EU's top exports to Vietnam and corresponding imports (2005-2014, HS1996 2-digit level)

Table 2-11: RCAs for the top 15 exporting products of the EU (2014)

Table 2-12: RCAs for the top 15 exporting products of Vietnam (2014)

Table 3-1: Comparative GLIs for EU-Vietnam, Vietnam-World and EU-World (2014, HS1996 6-digit level)

Table 3-2: RMAs for top 15 EU exports to Vietnam, with the world as comparator economy (2014, HS 1996 2-digit level)

Table 3-3: RMAs for top 15 Vietnamese exports to the EU, with the world as comparator economy (2014, HS 1996 2-digit level)

Table 3-4: FDI inflows to the EU and Vietnam, from 2007 to 2015, (in billion USD)

Table 3-5: Average FDI Regulatory Restrictiveness Index of the EU member states (20102015)

Table 3-6: The EU's top 10 restricted investment sectors (by average FRRI, 2010-2015)

Table 3-7: Current barriers to the EU's imports to Vietnam

Table 3-8: Respective Percentage of contract value of pharmaceutical products

Table 3-9: Vietnamese thresholds (in SDR) and coverage in the EVFTA 


\section{LIST OF FIGURES}

Figure 1-1: Vietnam's exports and imports to and from the EU (2005 to 2014)

Figure 2-2: The EU and Vietnam Average Tariffs (Simple), 2004-2014

Figure 2-3: Applied tariffs of the EU on imports from Vietnam by product (2014, Simple Average, HS 2-digit level)

Figure 2-4: Applied tariffs of Vietnam on imports from the EU by product (2014, Simple Average, HS 2-digit level)

Figure 2-5: Distribution of Vietnam's imports by partners (\%) (2005-2014)

Figure 2-6: Distribution of Vietnam's exports by partners (\%) (2005-2014)

Figure 2-7: Distribution of EU's imports by partners (\%) (2005-2014)

Figure 2-8: Distribution of EU’s exports by partners (\%) (2005-2014) 


\section{INTRODUCTION}

On $2^{\text {nd }}$ December 2015, the EU and Vietnam announced the conclusion of the negotiations for an EU-Vietnam Free Trade Agreement (EVFTA). The EVFTA is expected to create a free trade area among member economies. The EVFTA is of interest for several reasons.

Firstly, the EVFTA is created in the era of "next generation” trade agreement. It, therefore, is expected to extend is scope well beyond the limits of trade and trade-related policies. The EVFTA includes, which have already been addressed by the World Trade Organization (WTO) and other regional agreements such as investment, trade in services, technical barriers to trade and intellectual property rights. Moreover, the EVFTA is significant for its strong focus on sustainable development, sustainable management of natural resources or labour rights.

Secondly, the EVFTA is another FTA between the EU and an ASEAN member state. It is therefore considered as stepping stone towards an ultimate objective of a comprehensive region-to-region EU-ASEAN FTA.

Participating in such agreement will bring both opportunities and challenges for the member economies and there have been different opinions on potential impacts of the EVFTA to the member economies.

This research uses the Sussex Framework, which was introduced by Centre for the Analysis of Regional Integration at Sussex (CARIS), to provide insights into the potential implications of the EVFTA for participating countries ${ }^{1}$. By using the SF, this research is expected to answer the questions on who would be the gainers or losers of the FTA playground. The SF analyses the potential effects of regional trade agreements, based on international databases. The thesis focuses on trade effects in terms of trade creation and trade diversion introduced by Viner (1950). Within the limit of provided database, only statistical indicators of trade in goods will be used.

This research will be divided into 4 main parts. First, in Chapter 1 , background on the relationship between the EU and Vietnam as well as background on the EVFTA will be provided. Chapter 1 will also look into roles of the EVFTA to both countries as well as the roles of the FTA in the region context. Different rules of thumbs (RTs) under the SF Framework will be introduced in Chapter 2 and to discuss on how the EVFTA might benefit

\footnotetext{
${ }^{1}$ Evan, D. et al., 'Assessing Preferential Trading Agreements Using the Sussex Framework', CARIS Working Paper, 2007, No.01, (Accessed on $1^{\text {st }}$ April 2016), available at https://www.sussex.ac.uk/webteam/gateway/file.php?name $=$ cariswp01.pdf\&site $=261$
} 
the economics of both Vietnam and the EU. Similarly, Chapter 3 will base on deep integration to analyse questions on welfare gain or loss to the EU and Vietnam. To conclude, the research will give out some policy recommendations for Vietnam, as a developing country in Chapter 4. 


\section{CHAPTER 1: BACKGROUND ON THE EU - VIETNAM RELATIONSHIP}

\subsection{Diplomatic Relations between the EU and Vietnam}

The EU and Vietnam have formally established diplomatic relations since in 1990. In 1995, the EU and Vietnam signed a EU-Vietnam Framework Cooperation Agreement (FCA). On that year, the European Commission Delegation established the permanent representative in Vietnam. For over two decades, there have been significant milestones in the diplomatic relations between two countries.

In 1997, Vietnam joined in the ASEAN-EU Cooperation Agreement.

In 2003, an official dialogue between the EU and Vietnam on human rights was initiated.

In 2004, the first EU-Vietnam Summit was hosted in Hanoi.

In 2008, the EU and Vietnam negotiated for the Agreement on Partnership and Cooperation (PCA).

In 2012, EU-Vietnam Framework Agreement on Comprehensive Partnership and Cooperation (PCA) was signed. The European Parliament ratified the Agreement in December 2015.

In 2012, Vietnam and the EU launched EVFTA.

\subsection{The EU - Vietnam Trade Relations}

Bilateral trade and investment between the two economies have been strengthened steadily since 1990. Generally, the EU has been among the most important markets for Vietnamese exports and sources of imports. Since 2002, the EU and Vietnam concluded the bilateral negotiations of Vietnam's accession to the WTO, bilateral trade between the EU and Vietnam witness the significant increased.

There are some features that underline bilateral trade between the two economies. Firstly, Vietnam is famous for the agro-food sector and labour-intensive industries. With its strength in capital, technology and management expertise, the EU's ability to supply advanced technologies and machineries made the EU complimentary for Vietnam's manufacturing sectors $^{2}$. It is reason for growth of Vietnam's exports to the EU (from 2005 to 2014), represented in Figure 1-1.

\footnotetext{
2 'Guide to the EU-Vietnam Free Trade Agreement', Delegation of the European Union to Vietnam, 2016, (accessed $12^{\text {th }}$ April 2016), https://eeas.europa.eu/delegations/vietnam/documents/eu_vietnam/evfta_guide.pdf
} 
Figure 1-1: Vietnam's exports and imports to and from the EU (2005 to 2014)

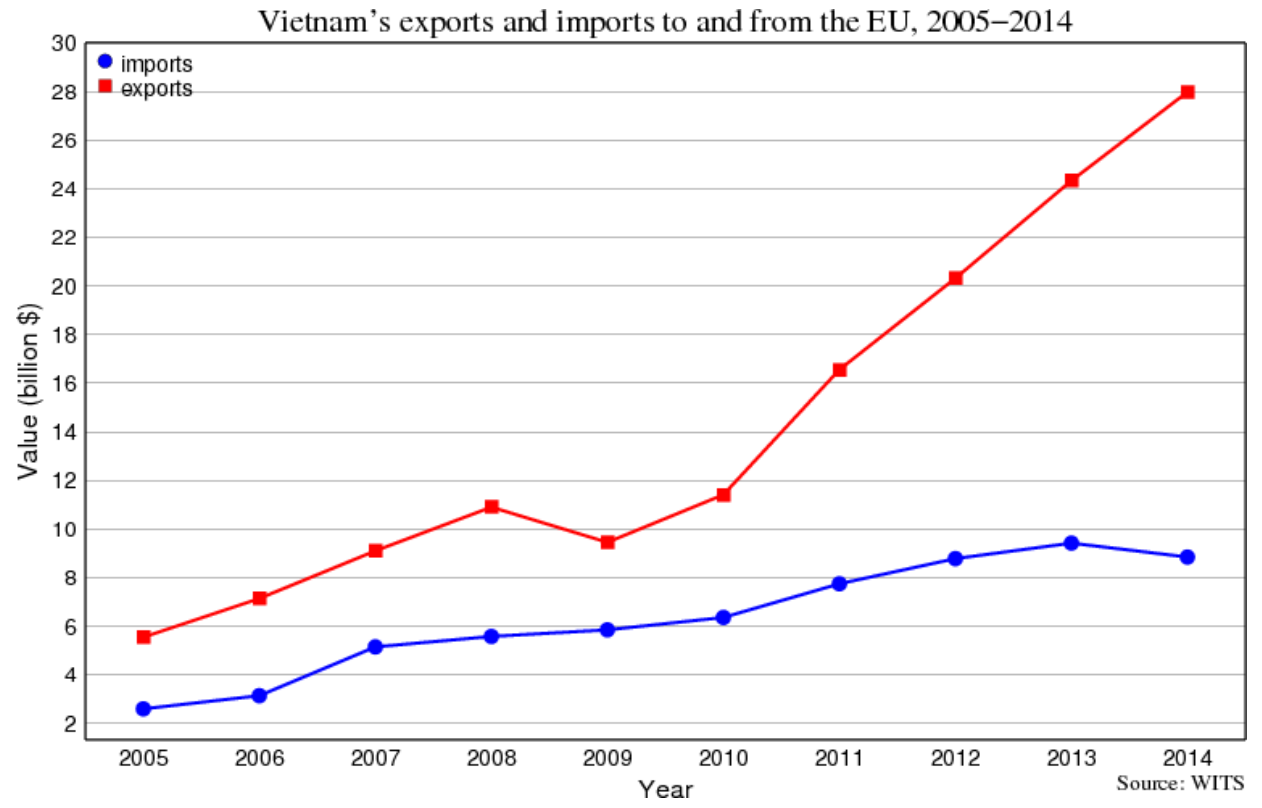

Secondly, strong commitment between the EU and Vietnam's leaders as well as political relationship is important factors for promoting bilateral trade. The EU has provided Vietnam with concessional loans and grants to accelerate Vietnam's reforms and international integration. For many years, the EU has offered unilaterally preferential treatments to widerange of commodities originating from Vietnam under the Generalised System of Preferences $(\mathrm{GSP})^{3}$.

Finally, Vietnam has shown to have dynamic and proactive business environment, which is crucial for harnessing trade opportunities. Success stories of Vietnamese fishery products to the EU's market, following with other products in the recent years such as electronics, computers, telephones, textiles and garments, or footwear have enable Vietnam to unlock international key markets, such as Japan and the United States. The EU-Vietnam is therefore expected to create momentum to strengthen trade ties between the two economies ${ }^{4}$.

In term of Investment, the EU has been a very important investor into Vietnam. The EU has always been in the top-5 of FDI partners of Vietnam. By the end of 2015, there have been 1730 FDI projects in Vietnam from the EU investors, contributing to more than 23.2 billion USD of FDI bumped into the country. In 2015, about 1.5 billion USD has been poured into Vietnam, making the EU $3^{\text {rd }}$ ranked of FDI partners in Vietnam.

\footnotetext{
${ }^{3}$ Ibid.

${ }^{4}$ Ibid.
} 


\subsection{The EU - Vietnam FTA and its roles in the region}

Firstly, as for the institutional structure of the EU - Vietnam FTA, A Trade Committee, plus specialised committees and working groups, will be responsible for ensuring the proper operation of the EU - Vietnam FTA. There are different bodies to provide both to seek resolution of market access and to engage in closer regulatory cooperation. Annually, the Trade Committee will meet and may decide on establishment of other specialised committees and working bodies to assist in its tasks.

Secondly, the EVFTA is evitable for the relationship between the EU and Vietnam in term of bilateral trade. Vietnam has currently enjoyed preferential access to the EU through the GSP, granted by the EU to developing countries. However, it is limited that Vietnam had only access for products defined unilaterally by the EU and the EU could change the conditions at any time. On the other hand, the EU had no preferential access to Vietnam. The implementation of the FTA is therefore considered as mutual benefit for both economies. Also, the EVFTA is believed to promote significant relationship between the EU and Vietnam as it emphasizes on sustainable development via core commitments on labour rights and environmental protection.

Additionally, the EVFTA has an important role in the region, as it is the second concluded agreement between the EU and ASEAN countries. ASEAN is among the key pillar for development in Asia with market potential. Also, after China, the EU is ASEAN's second largest trading partner. Therefore, strengthening trade between ASEAN is the EU's priority, expressing an ambitious trade agenda with ASEAN. Following the conclusion of the EUSingapore FTA, EU-Vietnam FTA is expected to be the second step of the EU into the ASEAN, promoting the on-going negotiation of FTA between the EU and Malaysia and Thailand, the newly launched FTA between the EU and the Philippines (launched in December 2015).

At regional level, the ultimate objective is for the bilateral FTAs under negotiation between the EU and individual ASEAN member countries to serve as building blocks towards an ambitious and comprehensive EU-ASEAN regional FTA ${ }^{5}$.

\footnotetext{
5 'Facts and figures: Free Trade Agreement between EU and Vietnam', European Commission Fact Sheet, 2015, (accessed 15 $5^{\text {th }}$ April 2016), http://europa.eu/rapid/press-release_MEMO-15-5468_en.htm
} 


\section{CHAPTER 2: EXPECTED SHALLOW INTEGRATION EFFECTS}

The Sussex Framework, which was developed by the CARIS, examines the potential impacts of a regional agreement based on both shallow integration and deep integration. Specifications of the SF explained in this section as well as implications will rely heavily on methodology published by CARIS ${ }^{6}$.

\subsection{Initial Tariff Lines}

This section specializes in the expected effects of shallow integration through tariff and trade data as inputs to the Sussex Framework. As for the first rule of thumb, it is that the higher are the tariffs, the higher is the likelihood of both trade creation and diversion. In this study, data on bilateral tariffs of the two economies have been downloaded from TRAINS database. The evolution of simple average tariffs between the EU and Vietnam over the last decade (2004 2014) is presented in Figure 2-1.

Figure 2-1: The EU and Vietnam Tariffs (Simple), 2004-2014

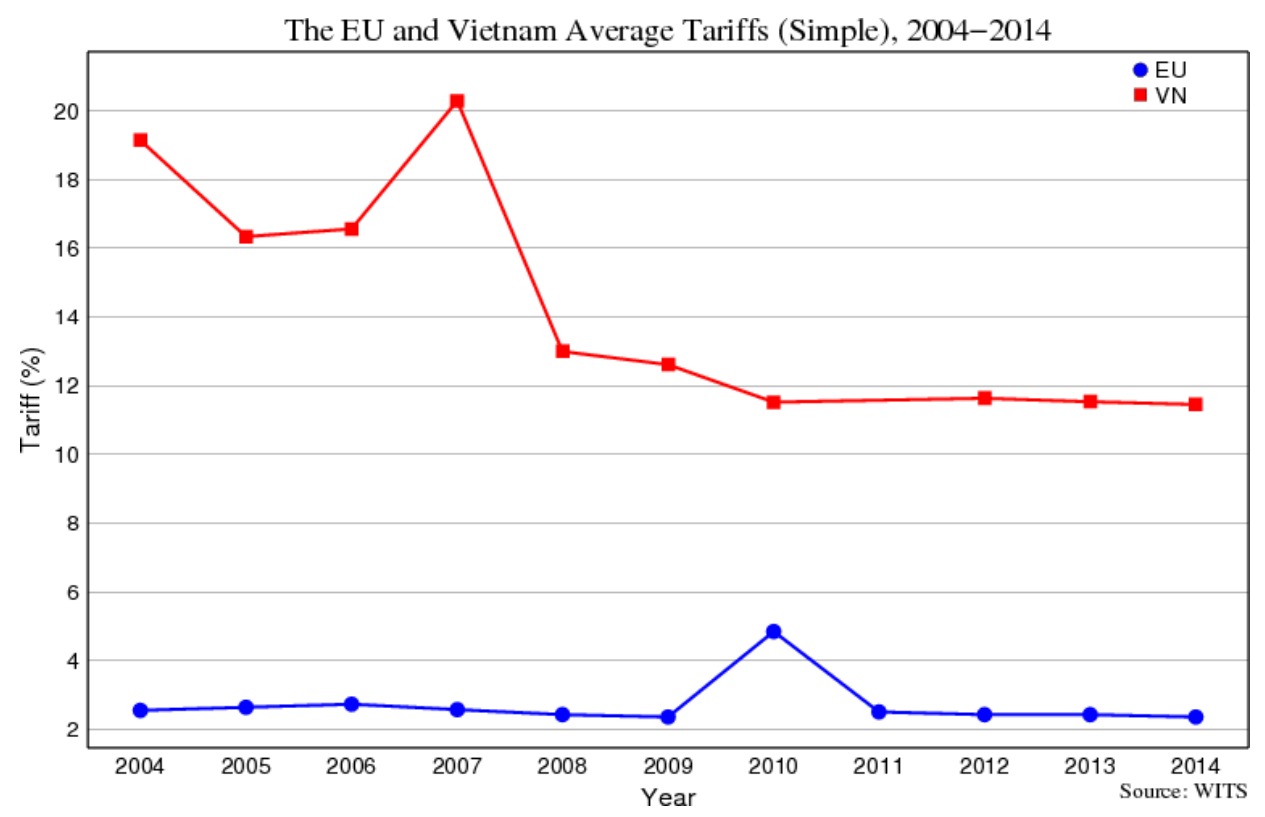

In this rule of thumb, the initial tariff levels between the two counties represent the expected trade creation and trade diversion effects. In general, it can be seen from Figure 4-1 that the tariff level of the EU has already been very low for the last 10 years, moderating around the rate of $2.5 \%$ in 2004 to $2.36 \%$ in 2014 . On the other hand, tariff level of Vietnam has witnessed a significant drop from $19.4 \%$ in 2004 to $11.46 \%$ in 2014, though remaining rather high compared to the EU. Therefore, suggestion from the tariff data is that the potential of

\footnotetext{
${ }^{6}$ Gasiorek, M. et al., 'Qualitative Analysis of a potential Free Trade Agreement between the European Union and India', Main Report, Centre for the Analysis of Regional Integration at Sussex, 2007, p.15-16
} 
both trade creation and trade diversion from shallow integration would be rather low for the EU and be higher for Vietnam as the FTA is into reality.

Although simple average tariffs draw a recommendation on general potential for trade creation and trade diversion, it hides significant variations on the dataset. Different indicators were therefore analysed to have a closer investigation on the expected trade creation and trade diversion. Table 2-2 illustrates indicators such as standard deviation, minimum and maximum tariffs, and domestic and international tariff peaks on bilateral imports of the two economies.

Table 2-2: Comparative bilateral tariff profiles of the EU and Vietnam (2004-2014)

\begin{tabular}{|c|c|c|c|c|c|c|c|c|}
\hline Country & Year & $\begin{array}{c}\text { Simple } \\
\text { Average }\end{array}$ & $\begin{array}{l}\text { Weighted } \\
\text { Average }\end{array}$ & $\begin{array}{l}\text { Standard } \\
\text { Deviation }\end{array}$ & $\begin{array}{l}\text { Min } \\
\text { Rate }\end{array}$ & $\begin{array}{l}\text { Max } \\
\text { Rate }\end{array}$ & $\begin{array}{c}\text { Domestic } \\
\text { Peaks (\%) }\end{array}$ & $\begin{array}{c}\text { International } \\
\text { Peak (\%) }\end{array}$ \\
\hline \multirow{11}{*}{ EU } & 2004 & 2.55 & 2.9 & 1.34 & 0.83 & 5.26 & 1.62 & 1.77 \\
\hline & 2005 & 2.64 & 2.88 & 1.33 & 0.92 & 5.16 & 1.55 & 1.57 \\
\hline & 2006 & 2.73 & 3.04 & 1.36 & 0.85 & 5.32 & 1.03 & 1.03 \\
\hline & 2007 & 2.57 & 2.75 & 1.33 & 0.69 & 5.04 & 1.37 & 1.06 \\
\hline & 2008 & 2.43 & 2.49 & 1.24 & 0.85 & 5.02 & 1.91 & 1.21 \\
\hline & 2009 & 2.36 & 2.45 & 1.37 & 0.62 & 5.05 & 1.54 & 1.15 \\
\hline & 2010 & 4.84 & 4.47 & 2.05 & 1.36 & 8.29 & 3.93 & 4.31 \\
\hline & 2011 & 2.5 & 2.5 & 1.37 & 0.81 & 5.39 & 1.17 & 1.19 \\
\hline & 2012 & 2.43 & 2.32 & 1.32 & 0.68 & 5.05 & 0.86 & 1.1 \\
\hline & 2013 & 2.43 & 2.51 & 1.39 & 0.64 & 5.19 & 1.34 & 1.49 \\
\hline & 2014 & 2.36 & 2.28 & 1.39 & 0.57 & 5.19 & 1.4 & 1.56 \\
\hline \multirow{11}{*}{ VN } & 2004 & 19.14 & 18.59 & 5.16 & 12.69 & 27.5 & 0.48 & 7.71 \\
\hline & 2005 & 16.33 & 15.58 & 5.04 & 10.15 & 24.81 & 0.6 & 7.94 \\
\hline & 2006 & 16.56 & 15.96 & 5.01 & 10.21 & 24.93 & 0.61 & 8.23 \\
\hline & 2007 & 20.28 & 19.31 & 5.58 & 12.74 & 28.99 & 0.58 & 10.28 \\
\hline & 2008 & 13 & 12.49 & 3.75 & 8.11 & 19.3 & 1.17 & 5.77 \\
\hline & 2009 & 12.61 & 12.19 & 4.03 & 7.53 & 19.49 & 0.84 & 6.23 \\
\hline & 2010 & 11.52 & 11.11 & 3.58 & 6.88 & 17.47 & 0.62 & 6.78 \\
\hline & 2011 & N/A & N/A & N/A & N/A & N/A & N/A & N/A \\
\hline & 2012 & 11.63 & 11.15 & 3.71 & 6.73 & 17.75 & 0.6 & 5.52 \\
\hline & 2013 & 11.53 & 11.04 & 3.72 & 6.61 & 17.65 & 0.6 & 7.13 \\
\hline & 2014 & 11.46 & 10.85 & 3.73 & 6.61 & 17.64 & 0.61 & 7.18 \\
\hline
\end{tabular}

From Table 3-2, it is shown that there were significant differences across tariff lines. For the EU, the percentage of both domestic tariff peaks and international tariff peaks was rather low over time, at $1.45 \%$ and $1.56 \%$ respectively in 2014 . Vietnam, on the other hand, experienced very low percentage of domestic peaks in comparison with international peaks, as $0.61 \%$ compared to $7.18 \%$ in 2014 . With higher maximum tariffs and applied tariff peaks for more products, Vietnam might enjoy greater magnitude for trade creation and trade diversion if these product categories are covered under the EU-Vietnam FTA. 
To continue with the analysis of trade creation and trade diversion derived from tariff lines, applied tariffs on imports of the EU and Vietnam by products were considered. Figure 2-3 and 2-4 in ANNEX A provided insights into tariff profiles by products of the EU and Vietnam in 2014. As for the European Union, tobacco and substitutes (code 24 - HS 2 digit) were the most protected at $13.84 \%$. Other products in top 5 of protection were fruits or vegetable preparations (code 20), diary products (code 04), apparels or clothing accessories (code 61) and preparations of meats and fish (code 16). Brief conclusion can be drawn from the figure that if those sectors are liberalized in the EVFTA, there will be considerable trend for both trade creation and trade diversion.

Similarly, tariff profiles of Vietnam shows wide range of commodities under tariff peaks, with the highest applied tariff in 2014 was for tobacco and substitutes (code 24) at more than $44 \%$. Other products, which were under high protection, are beverages (code 22), preparations of fruits and vegetable (code 20) and meat and fish preparations (code 16), with tariffs of 25\% at least. Other products might also enjoy trade creation and trade diversion if they are covered under the FTA that are edible fruits and nuts (code 08), articles of leather (code 42), footwear (code 64), vehicles except for railways (code 87) and miscellaneous manufactured articles (code 96).

In general, it can be recognized that some products are highly protected by both economies, which are tobacco and substitutes (code 24), fruit and vegetable preparations (code 20) and meat and fish preparations (code 16). With highly protected sectors, they are the most difficult to negotiate. It is proved as in both economies' tariff schedules of the announced FTA on 02 December 2015, there has not any significant changes in the tariff base rates for such protected categories ${ }^{7}$. Those product lines will be liberalized in 10-year phrase from the date of enforcement.

It can therefore be concluded that the exclusion of these protected products would eliminate the potential for both trade creation and trade diversion. Despite such conclusion, it should also be noted that trade creation and trade diversion also depend on the elasticity of supply and on the extent to which smaller tariffs bring differences in competitiveness among economies ${ }^{8}$. Other rules of thumb will explain such consideration.

\footnotetext{
${ }^{7}$ EU-Vietnam Free Trade Agreement, EU-Vietnam, Agreed Texted as of January 2016, Annex 2-c-i [hereinafter EVFTA]

${ }^{8}$ See note 6
} 


\subsection{Number of partners involved in the FTA}

This second rule of thumb bases on the number of partners involved in the negotiated FTA. The more numbers of partners in the FTA there are, the higher potential for trade creation as opposed to trade diversion will be. However, EU and Vietnam formed a bilateral FTA, with no further economics involved. In this situation, EU negotiated to only one partner who is Vietnam and Vietnam negotiated with the EC only but it represents the 28 Member States of the EU, the largest market in the globe. Also, with the already high level of trade within the EU (intra-EU trade), there will be higher potential for trade creation for Vietnam than trade diversion. The FTA would also decrease barriers to trade for Vietnam with all those countries that already have agreements in place with the EU.

\subsection{Share of total trade with potential partner}

Continuing on RT2, complete view about potential trade partner of both Vietnam and the EU will be examined in this section, and geographical distributions of trade for both Vietnam and EU are considered. As for RT3, the higher the initial share of trade with potential partner, the greater is the likelihood for a welfare-enhancing FTA. The scope for expansion will be limited if a country engages into an FTA with economics, with whom little trade is counted. Within this research, top five countries to which the EU and Vietnam export to and import from will be examined, as regards the shares of imports and exports to its partners. Also, trade volume with potential partners will also be considered to have more complete view on the potential free trade agreement.

Figure 2-5: Distribution of Vietnam's imports by partners (\%) (2005-2014)

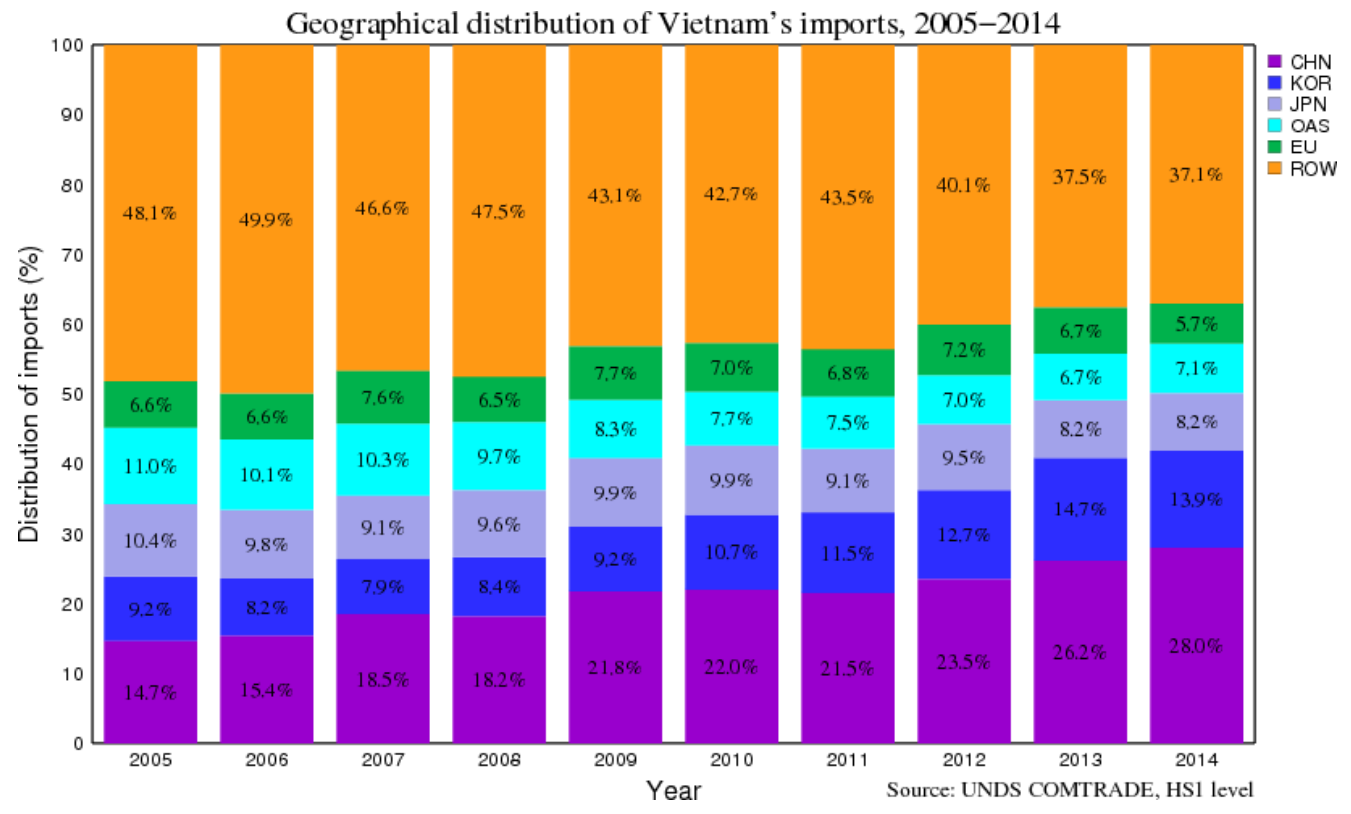


Figure 2-6: Distribution of Vietnam's exports by partners (\%) (2005-2014)

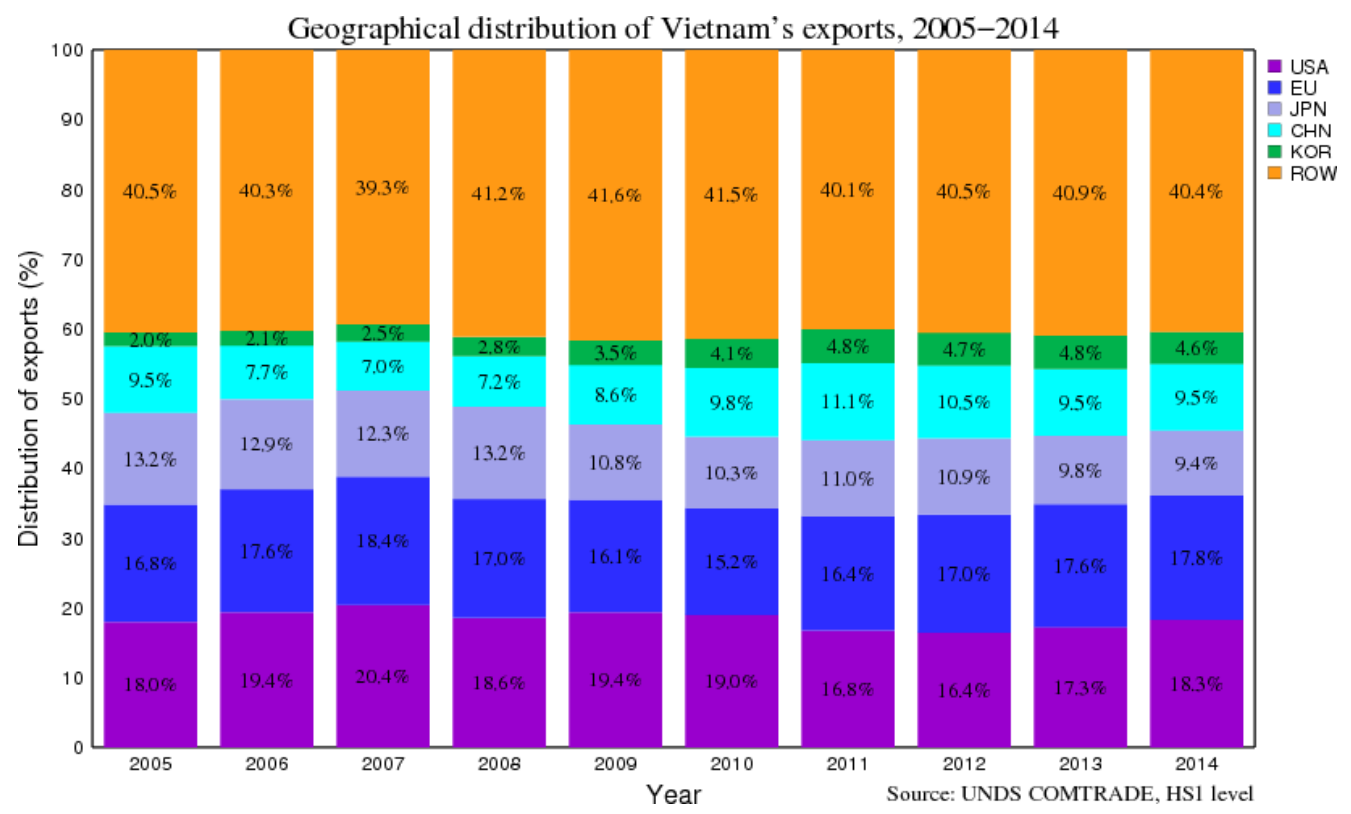

The above figures represent the 5 major trading partners of Vietnam over the 10-year period, from 2005 to 2014, in term of their imports and exports. Among main trading partners, Vietnam has not had FTAs with the EU and the US. With the recent announcement on the negotiation of the $\mathrm{TPP}^{9}$, an FTA with the EU is also the most looking forward agreement to Vietnam. The European Union is the second most important destination for exports from Vietnam, with around 17\% of Vietnam's exports (17.8\% in 2014). Also, imports from the EU have been ranging from $6 \%$ to $7 \%$ in total of Vietnamese imports $(5.7 \%$ in 2014$)$, ranked $5^{\text {th }}$ among importing partners of Vietnam. Therefore, it is likely that exports of Vietnam have already been destined to the very sufficient partner; potential for trade creation might increase. Also, it shall be considered that diversification of Vietnam's trade distribution will leave some potential for trade diversion.

\footnotetext{
9 'Trans-Pacific Partnership Leaders Statement', United States Trade Representative, 2011 (accessed $10^{\text {th }}$ July 2016), available at https://ustr.gov/about-us/policy-offices/press-office/press-releases/2011/november/transpacific-partnership-leaders-statement
} 
Figure 2-7: Distribution of EU's imports by partners (\%) (2005-2014)

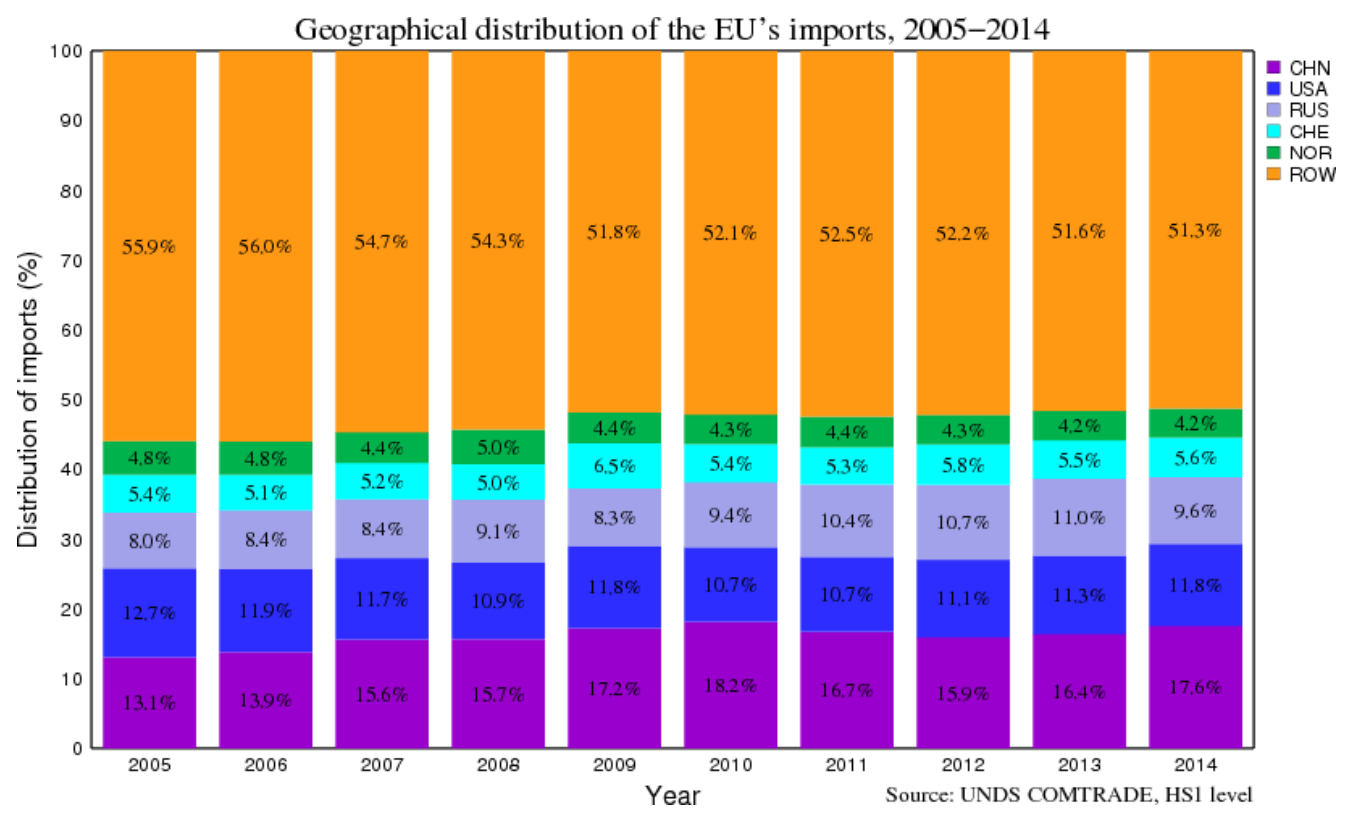

Figure 2-8: Distribution of EU's exports by partners (\%) (2005-2014)

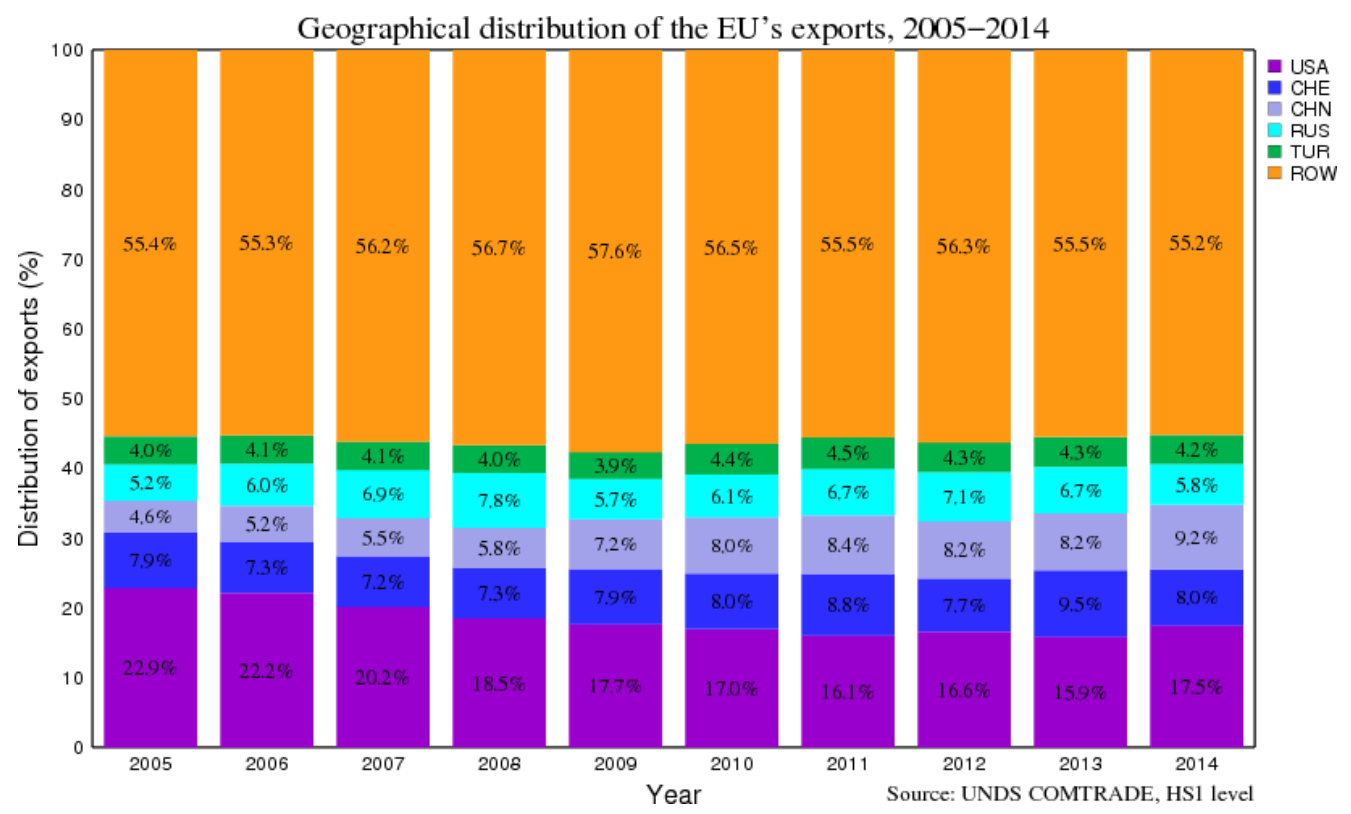

Similar analysis has been applied to geographical distribution of the European Union's imports and exports from 2005 to 2014. The EU's trading patterns look rather diversified with an interesting fact that top export and import partners of the EU are the USA, China, Switzerland and Russia. Vietnam is not in the list of important trading partners with the EU. The very low share of trade between the EU and Vietnam suggests that positive trade effects from shallow integration are expected to be low for the EU. Also, with the most important export destination and import source of the USA (accounting for 17.5\% of the EU's exports and $17.6 \%$ of the EU's imports in 2014), the recently announced negotiation of Trans-Atlantic 
Trade and Investment Partnership (TTIP), the trade effects of the EU-VN should be considered with trade diversion if TTIP comes into reality.

Beside geographical distribution of exports and imports of the TPP countries, it is also importation to look at share of specific products in trade among participating economies because it helps identify the most important product categories to each economy. And if the FTA covers such commodities, the likeliness of trade creation will increase. Moreover, as for the RT3, the higher are the shares of trade between potential partners for a certain product; the lower is the potential of trade creation. It is because these products seem to be most efficiently sourced from existing suppliers before the FTA is formed.

This below section will present commodity structures of Vietnam and the EU. The HS-1996 will be used to identify main trading sectors between the EU and Vietnam, on the 2-digit level. Table 2-9 explores the top exports and imports of Vietnam to the EU. It is shown that Vietnam experienced a concentrated export profile on the HS 2-digit level as top 10 of exports contributed to $83.3 \%$ of Vietnamese exports to the EU. Also, top three exported products, which were electrical machinery (code 85), footwear (code 64) and articles of apparel and clothing (code 62) account for almost half of export shares (at 48.97\%). The coverage of such categories under the FTA is crucial for the enhancement of welfare effects. It is also important, as the top 10 exports of Vietnam to the EU constitutes for $36.06 \%$ of its imports from the EU.

Table 2-9: Vietnam's top exports to the EU and corresponding imports (2005-2014, HS-1996 2-digit level)

\begin{tabular}{|c|c|c|l|l|l|c|c|}
\hline No & Country & Product & \multicolumn{1}{|c|}{ Product Name } & $\begin{array}{c}\text { Export Values } \\
(1000 \text { USD })\end{array}$ & $\begin{array}{c}\text { Export } \\
\text { Shares }\end{array}$ & $\begin{array}{c}\text { Import } \\
\text { Values } \\
\text { (1000 USD) }\end{array}$ & $\begin{array}{l}\text { Import } \\
\text { Shares }\end{array}$ \\
\hline 1 & Vietnam & 85 & Electrical machinery and parts & 36587553.74 & 22.57 & 5072010.708 & 9.32 \\
\hline 2 & Vietnam & 64 & Footwear, gaiters and the like & 28919626.36 & 17.84 & 68027.016 & 0.12 \\
\hline 3 & Vietnam & 62 & $\begin{array}{l}\text { Articles of apparel and clothing } \\
\text { accessories, not knitted }\end{array}$ & 13874089.59 & 8.56 & 114139.026 & 0.21 \\
\hline 4 & Vietnam & 9 & Coffee, tea, mate and spices & 12716625.7 & 7.85 & 22290.827 & 0.04 \\
\hline 5 & Vietnam & 84 & $\begin{array}{l}\text { Nuclear reactors, boilers, } \\
\text { machinery, etc. }\end{array}$ & 12077913.89 & 7.45 & 11768426.24 & 21.61 \\
\hline 6 & Vietnam & 94 & $\begin{array}{l}\text { Furniture, bedding, mattresses, } \\
\text { cushions, lamps and lights, etc. }\end{array}$ & 9303082.394 & 5.74 & 252105.16 & 0.46 \\
\hline 7 & Vietnam & 3 & $\begin{array}{l}\text { Fish and crustaceans and other } \\
\text { aquatic invertebrates }\end{array}$ & 8323394.285 & 5.14 & 934750.064 & 1.72 \\
\hline 8 & Vietnam & 61 & $\begin{array}{l}\text { Articles of apparel and clothing } \\
\text { accessories, knitted }\end{array}$ & 5176976.695 & 3.19 & 46894.537 & 0.09 \\
\hline
\end{tabular}




\begin{tabular}{|c|l|c|l|c|c|c|c|}
\hline 9 & Vietnam & 42 & $\begin{array}{l}\text { Leather goods, travel goods and } \\
\text { handbags, etc. }\end{array}$ & 4314795.231 & 2.66 & 77168.276 & 0.14 \\
\hline 10 & Vietnam & 39 & Plastic and articles thereof & 3725894.762 & 2.3 & 1278517.041 & 2.35 \\
\hline & Top 10 & & & $\mathbf{1 3 5 0 1 9 9 5 2 . 6}$ & $\mathbf{8 3 . 3}$ & $\mathbf{1 9 6 3 4 3 2 8 . 8 9}$ & $\mathbf{3 6 . 0 6}$ \\
\hline
\end{tabular}

Under the similar analysis, Table 2-10 sheds light on the EU's top exports to Vietnam and corresponding imports from 2005 to 2014, in terms of values and shares. As it can be seen that the EU's top 10 exports contributed for only $67.78 \%$ of its total exports to Vietnam, the EU is proven to have more diversified export profile. The corresponding import shares of the EU from Vietnam account for only 34.56\% of the economy's total imports from Vietnam (with volume of more than 56 billions of USD), it however outbreaks export values (almost 37 billions USD). Top export products of the EU to Vietnam are machinery appliances (code 84 ) at $21.61 \%$ while top imports from Vietnam are electrical machinery and parts (code 85 ) at $22.57 \%$.

Table 2-10: The EU's top exports to Vietnam and corresponding imports (2005-2014, HS-1996 2-digit level)

\begin{tabular}{|c|c|c|l|c|c|c|c|}
\hline No & Country & Product & Product Name & $\begin{array}{c}\text { Export Values } \\
(1000 \text { USD })\end{array}$ & $\begin{array}{c}\text { Export } \\
\text { Shares }\end{array}$ & $\begin{array}{c}\text { Import } \\
\text { Values } \\
(1000 \text { DS })\end{array}$ & $\begin{array}{c}\text { Import } \\
\text { Shares }\end{array}$ \\
\hline 1 & The EU & 84 & $\begin{array}{l}\text { Nuclear reactors, boilers, } \\
\text { machinery appliances, etc. }\end{array}$ & 11768426.24 & 21.61 & 12077913.89 & 7.45 \\
\hline 2 & The EU & 88 & $\begin{array}{l}\text { Aircraft, spacecraft and parts } \\
\text { thereof }\end{array}$ & 5332701.314 & 9.79 & 188216.936 & 0.12 \\
\hline 3 & The EU & 85 & Electrical machinery and parts & 5072010.708 & 9.32 & 36587553.74 & 22.57 \\
\hline 4 & The EU & 30 & Pharmaceutical products & 4100870.716 & 7.53 & 72296.584 & 0.04 \\
\hline 5 & The EU & 87 & $\begin{array}{l}\text { Vehicles except railway and } \\
\text { parts thereof }\end{array}$ & 2709521.781 & 4.98 & 1311316.073 & 0.81 \\
\hline 6 & The EU & 90 & $\begin{array}{l}\text { Optical, measuring instruments } \\
\text { and parts thereof }\end{array}$ & 2308427.822 & 4.24 & 1128740.906 & 0.7 \\
\hline 7 & The EU & 72 & Iron and steel & 1708407.855 & 3.14 & 521595.602 & 0.32 \\
\hline 9 & The EU & 38 & $\begin{array}{l}\text { Miscellaneous } \\
\text { products chemical }\end{array}$ & 1421582.726 & 2.61 & 127705.892 & 0.08 \\
\hline 10 & The EU & 41 & Raw hides and skins and leather & 1201289.315 & 2.21 & 307598.272 & 0.19 \\
\hline
\end{tabular}

Source: UNDS COMTRADE

Therefore, it can be concluded that the coverage of these product sectors under the FTA is essential for the positive trade effects. Also, product sectors such as electrical machinery appliances and parts thereof (Code 84 and 85) are considered as key factors for trade 
liberalization between the two economies. Again, looking into both the EU and Vietnam's Schedule on reduction and/or elimination of custom duties of such products in the announced FTA, the majority of product codes under those sectors were listed with B5 or B10 staging categories $^{10}$. It means that custom duties on originating goods shall be removed in six or eleven annual stages as soon as the Agreement enters into forces. The two economies will then have to delay the welfare enhancing effects of the Agreement into 5-year or 10-year times.

In addition to conclusion drawn from the data on HS 2-digit level, it is important to note that there might be inaccuracy in the analysis as HS 2-digit level is rather sensitive for level of disaggregation. The export concentration is therefore also examined on the HS 4-digit or HS 6-digit levels. The principle from that is the more diversified the export structure of the economy to its partner, the more likely it will bring trade creation. The Trade Concentration Index (TCI) was therefore explored under the Sussex Framework to compute bilateral export flows between partners, using trade flow data as inputs. The TCI is calculated as follow:

$$
\text { TCI by Product }{ }_{i j}=\sum_{k}\left(\frac{x_{i j}}{X_{i j}}\right)^{2}
$$

from which $x_{i j}$ is the country i's exports of product $k$ to country $j$, and $x_{i j}$ is country's i's total exports to country $j^{11}$

From the formula, the TCI is calculated as the sum of the square of shares of export categories out of total bilateral exports and the TCI thus ranges from 0 (completely diversified) to 1 (completely concentrated).

Following the above calculation, the TCI for Vietnamese exports to the EU at 6-digit level in 2014 was 0.097 and the corresponding figure of European exports to Vietnam was 0.011. It is therefore suggested that export profiles of both Vietnam and the EU are extremely diversified, potential for trade creation within the formation of the FTA.

\subsection{Reveal Comparative Advantage (RCA)}

The underlying principle of RT4 is that the more different the comparative advantages across economics are, the higher likeliness of trade creation is. It is based on the fact that countries producing wholly different ranges of products will have limited scopes for further specialization. Revealed Comparative Advantage Index was then introduced under the Sussex

\footnotetext{
${ }^{10}$ EVFTA, Annex 2-c-i, Annex 2-c-ii

${ }^{11}$ World Trade Organization, A Practical Guide to Trade Policy Analysis, WTO: Geneva, 2012, p.30
} 
Framework to quantify the extent of comparative advantages among participating countries. The RCA is formulated as follow:

$$
R C A_{i w}^{k}=\frac{\left(x_{i j} \mid x_{i t}\right)}{\left(x_{n j} \mid x_{n t}\right)}
$$

in which $X$ represents exports, $i$ is for an exporting country, $j$ is for a particular commodity, $t$ is for the set of all commodities and $n$ is for set of other countries. ${ }^{12}$

RCA calculates the shares of exportation of a particular product in a country's total exports to the share of that product's exports in a comparator country's total exports. If a country's share of exports exceeds that of comparator country, the country is considered to have comparative in that product. If RCA of a country in a particular product is larger than 1 , that country is assumed to have comparative product in that product. This section will investigate the RCA indices of top-15 product categories, HS 6-digit level of the two economies to the world in 2014. Corresponding RCAs of those products will also be analysed.

Table 2-11: RCAs for the top 15 exporting products of the EU (2014) - HS 6-digit

\begin{tabular}{|c|c|c|c|c|c|c|c|}
\hline No & Country & $\begin{array}{c}\text { Product } \\
\text { Code }\end{array}$ & Product Name & $\begin{array}{c}\text { Values } \\
\text { (1000USD) }\end{array}$ & Shares & $\begin{array}{l}\text { World } \\
\text { Shares }\end{array}$ & RCA \\
\hline 1 & The EU & 271000 & $\begin{array}{l}\text { Petroleum oils and oils obtained from } \\
\text { bituminous minerals other than crude }\end{array}$ & 115204151.1 & $5.24 \%$ & $5.44 \%$ & 0.96 \\
\hline 2 & The EU & 300490 & Packaged medicines for retail & 77054946.3 & $3.51 \%$ & $1.25 \%$ & 2.81 \\
\hline 3 & The EU & 870323 & $\begin{array}{l}\text { Motorcars and other motor vehicles } \\
\text { principally designed for the transport of } \\
\text { person, cylinder capacity }<3000 \mathrm{cc}\end{array}$ & 76025298.89 & $3.46 \%$ & $1.28 \%$ & 2.7 \\
\hline 4 & The EU & 880240 & $\begin{array}{l}\text { Airplanes and other powered aircraft of } \\
\text { an unladed weight }>15,000 \mathrm{~kg}\end{array}$ & 45911797.23 & $2.09 \%$ & $0.35 \%$ & 5.98 \\
\hline 5 & The EU & 870324 & $\begin{array}{l}\text { Motorcars and other motor vehicles } \\
\text { principally designed for the transport of } \\
\text { person, cylinder capacity }>3000 \mathrm{cc}\end{array}$ & 34932330.57 & $1.59 \%$ & $0.57 \%$ & 2.77 \\
\hline 6 & The EU & 710813 & $\begin{array}{l}\text { Non-monetary: Gold including gold } \\
\text { plated with platinum and other semi- } \\
\text { manufactured forms }\end{array}$ & 30653110.06 & $1.40 \%$ & $0.21 \%$ & 6.66 \\
\hline 7 & The EU & 300210 & $\begin{array}{l}\text { Antisera and other blood fractions and } \\
\text { modified immunological products }\end{array}$ & 21566176.98 & $0.98 \%$ & $0.44 \%$ & 2.24 \\
\hline 8 & The EU & 880330 & $\begin{array}{lllll}\begin{array}{l}\text { Other parts of } \\
\text { helicopters }\end{array} & \text { aero planes or } & & & \\
\end{array}$ & 19684959.52 & $0.90 \%$ & $0.32 \%$ & 2.81 \\
\hline 9 & The EU & 870332 & $\begin{array}{l}\text { Motorcars and other motor vehicles } \\
\text { principally designed for the transport of } \\
\text { person, cylinder capacity }>1500 \text { cc but } \\
<=2500 \text { cc }\end{array}$ & 19358163.17 & $0.88 \%$ & $0.80 \%$ & 1.11 \\
\hline 10 & The EU & 841112 & Turbo-jets of a thrust exceeding $25 \mathrm{kN}$ & 16380887.45 & $0.75 \%$ & $0.07 \%$ & 10.2 \\
\hline 11 & The EU & 710812 & $\begin{array}{l}\text { Non-monetary: Gold including gold } \\
\text { plated with platinum and unwrought }\end{array}$ & 15740441.76 & $0.72 \%$ & $1.36 \%$ & 0.53 \\
\hline 12 & The EU & 854230 & $\begin{array}{l}\text { Electronic integrated circuits, } \\
\text { monolithic, analog or analog/digital }\end{array}$ & 14910959.96 & $0.68 \%$ & $2.92 \%$ & 0.23 \\
\hline
\end{tabular}

${ }^{12}$ Ibid.p.26 


\begin{tabular}{|c|c|c|l|c|c|c|c|}
\hline 13 & The EU & 841191 & Parts of turbo-jets or turbo-propellers & 14358478.38 & $0.65 \%$ & $0.13 \%$ & 5.04 \\
\hline 14 & The EU & 870899 & $\begin{array}{l}\text { Other parts and accessories for the } \\
\text { motor vehicles of 8701-8705 }\end{array}$ & 14297488.72 & $0.65 \%$ & $0.59 \%$ & 1.1 \\
\hline 15 & The EU & 710231 & $\begin{array}{l}\text { Non-industrial diamonds unworked or } \\
\text { simply sawn, cleaved or brute }\end{array}$ & 14133967.06 & $0.64 \%$ & $0.15 \%$ & 4.21 \\
\hline & Total & & & & $\mathbf{2 4 . 1 4 \%}$ & $\mathbf{1 5 . 8 8} \%$ & \\
\hline & Average & & & & & 3.29 \\
\hline
\end{tabular}

Source: UNDS COMTRADE

Table 2-12: RCAs for the top 15 exporting products of Vietnam (2014) - HS 6-digit

\begin{tabular}{|c|c|c|c|c|c|c|c|}
\hline No & Country & $\begin{array}{l}\text { Product } \\
\text { Code }\end{array}$ & Product Name & $\begin{array}{c}\text { Values } \\
\text { (1000USD) }\end{array}$ & Shares & $\begin{array}{l}\text { World } \\
\text { Shares }\end{array}$ & RCA \\
\hline 1 & Vietnam & 852520 & $\begin{array}{l}\text { Transmission apparatus incorporating } \\
\text { reception } \\
\text { radiotelephony... }\end{array}$ & 21369105.52 & $14.28 \%$ & $1.18 \%$ & 12.06 \\
\hline 2 & Vietnam & 270900 & $\begin{array}{l}\text { Petroleum oils and oils obtained from } \\
\text { bituminous minerals, crude }\end{array}$ & 7224230.188 & $4.83 \%$ & $6.46 \%$ & 0.75 \\
\hline 3 & Vietnam & 090111 & Coffee, not roasted, not decaffeinated & 3267705.559 & $2.18 \%$ & $0.10 \%$ & 22.43 \\
\hline 4 & Vietnam & 847130 & $\begin{array}{l}\text { Portable digital automatic data } \\
\text { processing machines }\end{array}$ & 3166515.001 & $2.12 \%$ & $0.84 \%$ & 2.52 \\
\hline 5 & Vietnam & 100630 & $\begin{array}{l}\text { Semi-milled or wholly milled rice, } \\
\text { whether or not polished/glazed }\end{array}$ & 2852872.577 & $1.91 \%$ & $0.11 \%$ & 17.1 \\
\hline 6 & Vietnam & 640399 & $\begin{array}{l}\text { Other footwear w/o out soles of leather, } \\
\text { not covering ankle }\end{array}$ & 2741164.752 & $1.83 \%$ & $0.15 \%$ & 12.16 \\
\hline 7 & Vietnam & 030613 & $\begin{array}{l}\text { Shrimps and prawns, whether or not in } \\
\text { shell, frozen }\end{array}$ & 2490621.314 & $1.66 \%$ & $0.09 \%$ & 18.21 \\
\hline 8 & Vietnam & 847160 & $\begin{array}{l}\text { Input or output units for digital } \\
\text { automatic data-processing machines }\end{array}$ & 2342867.087 & $1.57 \%$ & $0.34 \%$ & 4.57 \\
\hline 9 & Vietnam & 854230 & $\begin{array}{l}\text { Electronic integrated circuits, } \\
\text { monolithic, analog or analog/digital }\end{array}$ & 2211454.459 & $1.48 \%$ & $2.65 \%$ & 0.56 \\
\hline 10 & Vietnam & 640411 & $\begin{array}{l}\text { Sports footwear with outer soles of } \\
\text { rubber or plastics and upper of textile } \\
\text { materials }\end{array}$ & 2202589.043 & $1.47 \%$ & $0.03 \%$ & 43.8 \\
\hline 11 & Vietnam & 851790 & $\begin{array}{l}\text { Parts of electrical apparatus for line } \\
\text { telephony or line telegraphy }\end{array}$ & 2073873.766 & $1.39 \%$ & $0.70 \%$ & 1.98 \\
\hline 12 & Vietnam & 030420 & Herrings, fresh or chilled & 2055155.062 & $1.37 \%$ & $0.07 \%$ & 19.51 \\
\hline 13 & Vietnam & 854430 & $\begin{array}{l}\text { Ignition wiring sets and other wiring } \\
\text { sets for vehicles, aircrafts or ships }\end{array}$ & 1962344.483 & $1.31 \%$ & $0.18 \%$ & 7.16 \\
\hline 14 & Vietnam & 080132 & Cashew nuts, shelled & 1930396.153 & $1.29 \%$ & $0.01 \%$ & $\begin{array}{c}149.8 \\
9\end{array}$ \\
\hline \multirow[t]{3}{*}{15} & Vietnam & 900691 & $\begin{array}{l}\text { Parts and accessories for photographic } \\
\text { cameras }\end{array}$ & 1840120.521 & $1.23 \%$ & $0.01 \%$ & $\begin{array}{c}157.1 \\
2 \\
\end{array}$ \\
\hline & Total & & & & $39.92 \%$ & $12.92 \%$ & \\
\hline & Average & & & & & & 31.32 \\
\hline
\end{tabular}

Table 2-11 and 2-12 provides data on exported commodities from the EU and Vietnam to the world, present similarities and differences between export profiles of the two economies in 
2014. Top-15 exporting categories of the EU contributed for only $24.14 \%$ of its total exports while contributing 39.92\% of Vietnamese total exports. That means the EU's export profile is more diversified, underpinning the previous TCI analysis in RT3. Comparing the top-15 exporting products of the two economies, there is only one product category (HS 6-ditgit code 854230 - electronic integrated circuits) that can be found in top exported commodities of both the EU and Vietnam. As RCAs of both economies in this sector is below 1 (0.23 in the EU and 0.56 in Vietnam), the EU and Vietnam are disadvantage in such products compared to the world and there might be likelihood for trade diversion. Other products of disadvantages in the two economies are petroleum category (HS271000 in the EU and HS270900 in Vietnam). The recent FTA between the EU and Vietnam could lead for both economies sourcing these commodities from each other, displacing already more efficient suppliers.

Oh the other hand, major differences between 2 countries and variety of export profiles suggest relatively potential for trade creation. Also the value of RCAs enhances the significant polarity in comparative advantages of the two areas, increasing likeliness trade creation.

From Table 2-11, the average RCA of the EU's top-15 exporting commodities was 3.29. Thus, the EU seems to have comparative advantages in the aircraft and automobile industries, such as code 880240 , code 841112 and code 841191 with very high RCAs of 5.98, 10.02 and 5.04 respectively. On the contrary, with the average RCA for top-15 exports of 31.32, Vietnam is considered to be very competitive in its export profiles (shown in Table 2-12). Electrical machine equipment parts (code 852520) is the most important product to Vietnamese exportation while it contributed more than 21 billion USD to Vietnam in 2014, and it has rather high RCA of 12.06. Moreover, Vietnam enjoys very high RCAs in a wide range of agricultural products such as cashew nuts (RCA of 149.89 for code 080132); fishery products (RCAs of 19.51 for code 030420 and 18.21 for code 030613); rice (RCA of 17.1 for code 100630); and coffee (RCA of 22.42 for code 090111). Other products of high competitiveness of Vietnam can be named is footwear (code 640411) with RCA of 43.8. To confirm the results of RCA indicators, RCA indices of top 15 product categories, HS 1996 4-digit level, of both economies in 2014 have also been looked into. Table 2-13 and 2-14 in Annex C compare information on comparative advantages in products of the EU and Vietnam. Again, those tables confirm comparative advantages of Vietnam in agricultural products such as coffee (code 0901), rice (code 1006) or aqua-cultural products (code 0304) and footwear (code 6403) or apparels (code 6203 and 6204) and those of the EU in aircraft and automobile industries (code 8802 or 8411). As from those table, Vietnam and the EU shared only one product category in the top 15 of exporting products which were telephone 
sets or apparatus for the transmission or reception of voice (Code 8517). Also, RCA of that product category in the EU was just 0.73 that means the EU is assumed to have less comparative advantages in that product. Vietnam, on the other hand, enjoyed the RCA index of 1.79 for telephone sets. Therefore, with the formation of FTA, the EU seems to be able to source from Vietnam these products. In short, RCA indicators suggest considerable potential for trade creation in the above-mentioned sectors within the EU-Vietnam FTA.

\subsection{Similarity of product mixes in the two economies}

As for the potential welfare of the FTA, similarity of production patterns among participating economies is assessed. The principle underlying RT5 is that the higher the similarity between countries is, the higher the potential for trade creation can occur. It is because integration enhance potential for countries to source the commodities from more efficient suppliers, replacing insufficient domestic suppliers.

The Finger-Freinin Index (FKI) is introduced under the SF to compute the overlap of trade among partners. The FKI is calculated as follow:

$$
F K_{i j}=1-\left[\frac{1}{2} \sum_{k}\left|\left(X_{i k} / \sum_{k} X_{i k}\right)-\left(X_{j k} / \sum_{k} X_{j k}\right)\right|\right]
$$

in which $X_{i k}$ is country i's exports of product $k$ and $X_{j k}$ is country j's exports of product $k^{13}$.

The calculation of FKI should be via using production data. Due to unavailability of data, trade data is used as indirect reflection of production. The FKI takes the minimum value across the two partners from the shares of exports in each sector out of total exports, at HS 6digit disaggregate level, and it ranges from 0 to 1 . When the FKI is equal to 0 , it means export profiles of two economies are totally different. The total overlap in export structures of two countries results in the FKI of 1 . Also, the SF suggests that FKI of over 0.4 is considered as relatively high $^{14}$.

Using above formula, FKI for export profiles of the EU and Vietnam is 0.2, which constitutes relatively dissimilar export patterns between the two. Incomparable production mixes between the two economies provide little potential for trade creation from production side. The result is then proved by the fact from RT4 analysis as welfare effects of the FTA then is reasoned by different comparative advantages between the EU and Vietnam.

\footnotetext{
${ }^{13}$ Finger, J.M. \& Kreinin, M.E. 'A Measure of 'Export Similarity' and its possible use', Economic Journal, 89, 1979, pp.905-912

14 Ibid.
} 


\subsection{Conclusion on shallow integration}

In general, the conclusion of the EU-Vietnam FTA is considered to be quite for Vietnam to increase its exports to the EU. The breakdown of border barriers is potential for increasing trade between the EU and Vietnam, although the already low average tariff of the EU. It is because Vietnam would have opportunity to access to access to the largest market in the world, consisting of 28 Member States, and also access to other markets that the EU currently has agreement with. The recent withdrawal of the UK from the EU would also affect the market access of Vietnam to the EU. However, within the scope of this research, the UK market is still included, as the UK has not officially negotiated the exit to the EU. Secondly, with the fact that the EU is a natural trading partner of Vietnam, the second most important export destination and the fifth most important import source, Vietnam is expected to benefit from such welfare enhancement. This consideration is also confirmed with the increasing volumes of trade between Vietnam and the EU. Thirdly, the relative low TCI represents rather diversified export portfolio of Vietnam, leaving room for trade creation. Last but not least, very high competitiveness in main exporting sectors of Vietnam suggests considerable potential for trade creation for Vietnam in the EU market. Vietnam would continue to enjoy favourable trade in sectors such as agricultural products, footwear or electrical machine equipment parts.

As for the EU, the welfare gain deriving from shallow integration of the EU-Vietnam FTA seems to be moderate. The most considerable potential for trade creation is the liberalization of tariff barriers of Vietnam. With relatively high tariff profiles, Vietnam seems to create more opportunities for European exports. Also with the commitment to cut the tariffs line in protected sectors in 5 years and 10 years, market access level in the area covered by the FTA will increase promisingly ${ }^{15}$. Different from above promising welfare the non-natural trading partner status of Vietnam to the EU and also the dissimilarity in product mixes between the EU and Vietnam, reflecting through low FKI would also suggest less potential for trade creation.

Taken as a whole, shallow integration from the EU-Vietnam FTA suggest limited opportunities for the EU compared to Vietnam. However, during the negotiation, the EU put major efforts on regulatory barriers and other non-tariff barriers, which might suggest that the EU benefits the most from deep integration. The discussion on expected findings from deep

\footnotetext{
${ }^{15}$ See note 10
} 
integration, dealing mostly with NTBs, regulatory barriers, is followed in the next section of this research. 


\section{CHAPTER 3: EXPECTED DEEP INTEGRATION EFFECTS}

Within the SF, there were no rules of thumb introduced, but it is divided into quantitative and qualitative analysis. As for the quantitative analysis, some indicators were suggested then different aspects of the FTA to be examined through qualitative assessment. This section assesses on the potential effects from deep integration between the EU and Vietnam, using both quantitative and qualitative analysis.

\subsection{Quantitative}

\subsubsection{Intra-industry trade (GLI)}

The Intra-industry trade (IIT) is one of the main indicators, introduced under the SF to generate welfare gains. The IIT has three forms, which are trade of similar goods with similar qualities and prices, trade of similar goods with different qualities and prices, and trade of commodities within the same classification representing a vertical supply chain ${ }^{16}$. The SF uses Gruber-Lloyd Index (GLI) to assess existing level of IIT. The GLI across all goods is calculated as:

$$
G L I_{i j}=1-\frac{\sum_{k}\left|x_{i j}^{k}-m_{i j}^{k}\right|}{X_{i j}+M_{i j}}
$$

in which $X_{i j}$ is export and $M_{i j}$ is import from country i to country $j$. Also the average GLI is weighted by the share of each good in total trade between country $i$ and $j^{17}$.

GLI measures the overlaps between exports and imports of all commodities. If there is no overlap between imports and exports, the GLI is 0 and no intra-industry trade occurs. In contrast, GLI equal to 1 means imports and exports are equal in all sectors.

Firstly, from the above calculation, the ITT level between the EU and Vietnam in 2014 is 0.059, which is considered to be rather low. That means the EU-Vietnam bilateral intraindustry trade accounts for only 5.9\% of total trade. Table 3-1 also compares intra-industry level between the EU and Vietnam to each economy's intra-industry level to the world. The GLI of EU-World is at 0.505, which mean majority of EU's trade is intra-industry trade. Vietnam, on the other hand, has lower level of deep integration into the world.

\footnotetext{
16 Shelburne, R. \& Jorge, G. 'The Role of Intra-Industry Trade in Service Sector', in Plummer, M. (ed.) Empirical Methods in International Trade: Essays in Honour Mordechai Kreinin, Edward Elgar Press, 2004, pp.110-128

${ }^{17}$ United Nations Conference on Trade and Development (UNCTAD), 'Module 5 - Practical regional trade analysis: Using international databases to analyse Regional Trade Agreements', Teaching Material on Regional Trade Agreements, 2010, p.145
} 
Table 3-1: Comparative GLIs for EU-Vietnam, Vietnam-World and EU-World

(2014, HS1996 6-digit level)

\begin{tabular}{|l|c|c|c|}
\hline & EU - Vietnam & Vietnam - World & EU - World \\
\hline Comparative GLIs & 0.059 & 0.241 & 0.505 \\
\hline
\end{tabular}

Source: UNDS COMTRADE

Low level of bilateral IIT suggests that the comprehensive FTA between the EU and Vietnam would increase potential for IIT between the two economies, also enormous welfare gains. Also, by dismantling barriers, Vietnam could also gain welfare with both the EU and the world. And welfare gain as intra-industry trade with the rest of the world for Vietnam seems to be larger than that with the EU.

\subsubsection{Revealed Market Access (RMA)}

Due to difference in intra-industry trade between countries, the SF also introduces Revealed Market Access Index (RMA) to assess potential welfare of deep integration. RMA is used to compare non-tariff barriers (NTBs) between two countries with a comparator economy. The level of exports into a market depends on the size of that market. Therefore, there are two forms of normalization, introduced by the SF to compare exports across two markets; one based on each receiving country's GDP and other based on total level of their imports. In this section, RMA normalized by imports will be used as below:

$$
R M A_{i j_{1} j_{2}}^{k}=\left(\frac{x_{i j_{1}}^{k}}{x_{j k_{2}}^{i}}\right)\left(\frac{\sum_{i} M_{j_{2}}}{\sum_{i} M_{j_{1}}}\right)
$$

where $k$ is the industry, $i$ is the country of origin, and $j_{1}$ and $j_{2}$ are the compared destination economies ${ }^{18}$

If the normalized value of exports for a commodity is less in one market than in the other, the value of RMA is less than 1. Even though RMA index is normalized by import demand, it still cannot capture other factors affecting integration such as tariffs, distance or common languages ${ }^{19}$. Therefore, comparator economies shall always be selected with careful consideration. Based on this foundation and due to the limitation of the research, the world was used as a comparator (assuming distance is similar) when NTBs in a particular country

${ }^{18}$ Rollo, J. 'Potential Effects of the Proposed Transatlantic Trade and Investment Partnership on Selected Developing Countries', Report Paper, CARIS, p.67, (accessed on $10^{\text {th }}$ July 2016), available at https://www.gov.uk/dfid-research-outputs/potential-effects-of-the-proposed-transatlantic-trade-and-investmentpartnership-on-selected-developing-countries

${ }^{19}$ Ibid. 
are examined. The RMA indices were calculated at the HS-2 digit level and were analysed for top 15 exports of a country to other.

Table 3-2: RMAs for top $15 \mathrm{EU}$ exports to Vietnam, with the world as comparator economy (2014, HS 1996 2-digit level)

\begin{tabular}{|c|c|c|c|c|c|c|c|}
\hline No & Country & $\begin{array}{l}\text { Product } \\
\text { code }\end{array}$ & Product name & $\begin{array}{c}\text { Value } \\
\text { (1000USD) }\end{array}$ & $\begin{array}{l}\text { To VN } \\
\text { Shares }\end{array}$ & $\begin{array}{l}\text { World } \\
\text { Shares }\end{array}$ & RMA \\
\hline 1 & The EU & 84 & $\begin{array}{l}\text { Nuclear reactors, boilers, machinery } \\
\text { \& mechanical appliances; parts } \\
\text { thereof }\end{array}$ & 3368184.05 & $19.89 \%$ & $16.66 \%$ & 2.32 \\
\hline 2 & The EU & 30 & Pharmaceutical products & 22335.364 & $8.75 \%$ & $6.31 \%$ & 55.13 \\
\hline 3 & The EU & 88 & Aircraft, spacecraft, and parts thereof & 74960.959 & $8.34 \%$ & $3.41 \%$ & 20.53 \\
\hline 4 & The EU & 85 & $\begin{array}{l}\text { Electrical machinery and equipment } \\
\text { and parts thereof }\end{array}$ & 10067208.09 & $7.14 \%$ & $7.95 \%$ & 0.48 \\
\hline 5 & The EU & 90 & $\begin{array}{l}\text { Optical, photographic, } \\
\text { cinematographic, measuring, } \\
\text { checking, precision instruments, etc. }\end{array}$ & 268418.358 & $4.89 \%$ & $4.71 \%$ & 1.68 \\
\hline 6 & The EU & 87 & $\begin{array}{l}\text { Vehicles other than railway tramway } \\
\text { roll-stock \& accessories }\end{array}$ & 251841.911 & $3.52 \%$ & $10.51 \%$ & 2.05 \\
\hline 7 & The EU & 41 & $\begin{array}{l}\text { Raw hides and skins (other than fur } \\
\text { skins) and leather. }\end{array}$ & 30650.416 & $3.04 \%$ & $0.20 \%$ & 12.93 \\
\hline 8 & The EU & 3 & $\begin{array}{l}\text { Fish \& crustacean, mollusc \& other } \\
\text { aquatic invertebrate }\end{array}$ & 869328.436 & $2.89 \%$ & $0.20 \%$ & 2.33 \\
\hline 9 & The EU & 38 & Miscellaneous chemical products & 20617.557 & $2.66 \%$ & $1.32 \%$ & 5.95 \\
\hline 10 & The EU & 39 & Plastics and articles thereof & 648665.83 & $2.61 \%$ & $2.79 \%$ & 1.76 \\
\hline 11 & The EU & 23 & $\begin{array}{l}\text { Residues \& waste from the food } \\
\text { industry; prepared animal fodder }\end{array}$ & 14394.689 & $2.46 \%$ & $0.24 \%$ & 14.85 \\
\hline 12 & The EU & 72 & Iron and steel & 111669.605 & $1.71 \%$ & $1.69 \%$ & 1.4 \\
\hline 13 & The EU & 71 & $\begin{array}{l}\text { Natural/cultured pearls, precious } \\
\text { stones \& metals, coin etc. }\end{array}$ & 155981.278 & $1.69 \%$ & $4.00 \%$ & 3.1 \\
\hline 14 & The EU & 11 & $\begin{array}{l}\text { Products of the milling industry; } \\
\text { malt; starches; inulin; wheat gluten }\end{array}$ & 3525.176 & $1.69 \%$ & $0.15 \%$ & 2.3 \\
\hline 15 & The EU & 44 & $\begin{array}{l}\text { Wood and articles of wood; wood } \\
\text { charcoal }\end{array}$ & 87400.782 & $1.67 \%$ & $0.66 \%$ & 1.38 \\
\hline
\end{tabular}

Source: UNDS COMTRADE

Table 3-2 examines market access level of Vietnam via looking to the European exports to Vietnam and the world, as comparator economies. After normalizing with imports, it is considerable that the EU exporting to Vietnam in those above products than to the world, except for only electrical machinery and equipment parts (code 85). It is assumed that distances between EU-Vietnam and EU-World are similar; the above RMAs suggest that market access barriers for those commodities in Vietnamese market are relatively low. 
Table 3-3: RMAs for top 15 Vietnamese exports to the EU, with the world as comparator economy (2014, HS 1996 2-digit level)

\begin{tabular}{|c|c|c|c|c|c|c|c|}
\hline No & Country & $\begin{array}{l}\text { Product } \\
\text { Code }\end{array}$ & Product Name & $\begin{array}{c}\text { Values } \\
\text { (1000USD) }\end{array}$ & $\begin{array}{l}\text { To EU } \\
\text { Shares }\end{array}$ & $\begin{array}{l}\text { World } \\
\text { Shares }\end{array}$ & RMA \\
\hline 1 & Vietnam & 85 & $\begin{array}{l}\text { Electrical machinery and equipment } \\
\text { and parts thereof }\end{array}$ & 10067208.09 & $34.25 \%$ & $24.24 \%$ & 2.3 \\
\hline 2 & Vietnam & 64 & $\begin{array}{l}\text { Footwear, gaiters and the like; parts } \\
\text { of such articles }\end{array}$ & 3690897.482 & $12.56 \%$ & $7.12 \%$ & 2.93 \\
\hline 3 & Vietnam & 84 & $\begin{array}{l}\text { Nuclear reactors, boilers, machinery } \\
\text { \& mechanical appliances; parts } \\
\text { thereof }\end{array}$ & 3368184.05 & $11.46 \%$ & $5.98 \%$ & 1.33 \\
\hline 4 & Vietnam & 62 & $\begin{array}{l}\text { Art of apparel \& clothing access, not } \\
\text { knitted/crocheted }\end{array}$ & 2175764.337 & $7.40 \%$ & $7.00 \%$ & 1.57 \\
\hline 5 & Vietnam & 9 & Coffee, tea, mate and spices. & 1768404.182 & $6.02 \%$ & $3.24 \%$ & 4.83 \\
\hline 6 & Vietnam & 94 & $\begin{array}{l}\text { Furniture; bedding, mattress, mattress } \\
\text { support, cushion etc. }\end{array}$ & 1086145.293 & $3.70 \%$ & $3.34 \%$ & 1.26 \\
\hline 7 & Vietnam & 3 & $\begin{array}{l}\text { Fish \& crustaceans, mollusc \& other } \\
\text { aquatic invertebrate }\end{array}$ & 869328.436 & $2.96 \%$ & $3.84 \%$ & 2.39 \\
\hline 8 & Vietnam & 61 & $\begin{array}{l}\text { Art of apparel \& clothing accessories } \\
\text { knitted or crocheted. }\end{array}$ & 793934.5 & $2.70 \%$ & $6.11 \%$ & 1.26 \\
\hline 9 & Vietnam & 42 & $\begin{array}{l}\text { Articles of leather; saddler/harness; } \\
\text { travel goods etc. }\end{array}$ & 684581.673 & $2.33 \%$ & $1.56 \%$ & 1.17 \\
\hline 10 & Vietnam & 39 & Plastics and articles thereof. & 648665.83 & $2.21 \%$ & $1.82 \%$ & 1.49 \\
\hline 11 & Vietnam & 8 & $\begin{array}{l}\text { Edible fruit and nuts; peel of citrus } \\
\text { fruit or melons. }\end{array}$ & 453249.354 & $1.54 \%$ & $1.71 \%$ & 2.28 \\
\hline 12 & Vietnam & 73 & Articles of iron or steel. & 410832.352 & $1.40 \%$ & $1.16 \%$ & 1.08 \\
\hline 13 & Vietnam & 16 & $\begin{array}{l}\text { Prep of meat, fish or crustaceans, } \\
\text { molluscs etc. }\end{array}$ & 335341.254 & $1.14 \%$ & $1.34 \%$ & 2.7 \\
\hline 14 & Vietnam & 90 & $\begin{array}{l}\text { Optical, photographic, } \\
\text { cinematographic, measuring, } \\
\text { checking, precision instruments, etc. }\end{array}$ & 268418.358 & $0.91 \%$ & $2.05 \%$ & 0.31 \\
\hline 15 & Vietnam & 40 & Rubber and articles thereof. & 262745.335 & $0.89 \%$ & $1.83 \%$ & 0.63 \\
\hline
\end{tabular}

Source: UNDS COMTRADE

Similar analysis applied to access NTBs in the European market, by measuring top Vietnamese exports to the EU and the world as comparator economy. Significant market access barriers for Vietnamese exports in the European Market are only for optical instrument (code 90) and rubber and articles (code 40).

Generally, it can be seen that bilateral trade between the EU and Vietnam do not experience considerable market access barriers. Therefore, if the FTA tackles NTBs in those above products to both Vietnam and the EU, welfare enhancement will increase for both, increasing potential benefit from deep integration. 


\subsection{Qualitative}

\subsubsection{Foreign Direct Investment \& Trade in Services}

\section{Foreign Direct Investment}

As for new-generation agreement, foreign direct investment (FDI) is a very important source for welfare gains from deep integration, as they enhance productivity via technology transfers, quality improvement and specialization ${ }^{20}$.

Table 3-4: FDI inflows to the EU and Vietnam, from 2007 to 2015, (in billion USD)

\begin{tabular}{|c|c|c|c|c|c|c|c|c|c|}
\hline Country & $\mathbf{2 0 0 7}$ & $\mathbf{2 0 0 8}$ & $\mathbf{2 0 0 9}$ & $\mathbf{2 0 1 0}$ & $\mathbf{2 0 1 1}$ & $\mathbf{2 0 1 2}$ & $\mathbf{2 0 1 3}$ & $\mathbf{2 0 1 4}$ & $\mathbf{2 0 1 5}$ \\
\hline EUU & $1,661.98$ & $1,077.16$ & 445.48 & 601.53 & 841.42 & 699.91 & 622.25 & 402.04 & 515.20 \\
\hline VNM & 6.7 & 9.579 & 7.6 & 8.0 & 7.43 & 8.368 & 8.9 & 92.0 & 118.0 \\
\hline
\end{tabular}

Source: Worldbank

As from Table 3-4, there has been contrast trend in FDI inflows between the EU and Vietnam. Vietnam has enjoyed sharp increase in FDI inflows, from more than 6.7 billion USD in 2007 to 118 billion USD in 2015; the inbound investment into the EU on the other hand has dropped by two-third in less than a decade (from 1,661.98 to 515.20 billion USD). Firstly, reported by the Deustche Bank, the European Union has lost its position as first-ranked recipient of FDI. Also, among total inward FDI flows into the EU, 60\% of them is intra-EU investment, which is considered as a shift of capital among the EU member states ${ }^{21}$.

To examine the barriers to FDI inflows into a country, the OECD introduced FDI Regulatory Restrictiveness Index (FRRI). Due to lack of data, only FDI Regulatory Restrictiveness Indices of majority of the EU countries are presented in Table 3-5 in the Annex B. It can be seen that FRRIs of European countries are relatively low. Average FRRI of European countries is 0.035. Beside rather low restrictiveness in FDI, there are some sectors that are rather restricted to FDI in the EU. The liberalization of such FDI sectors under the EUVietnam FTA will enhance the welfare gains of deep integration. Table 3-6 listed top 10 restricted sectors for investment into the EU market. The most restricted sector in the EU market can be named as real estate investment, fisheries, air, etc. From the EU's Schedule of

\footnotetext{
20 Organisation for Economic Co-operation and Development (OECD), Foreign Direct Investment for Development - Maximising Benefits, Minimising Costs, OECD Secretariat: France, 2002, p.12, (accessed on $10^{\text {th }}$ July 2016), available at https://www.oecd.org/investment/investmentfordevelopment/1959815.pdf

${ }^{21}$ Vetter, S., 'Recent Trends in FDI Activity in Europe - Regaining lost ground to accelerate growth', Deustche Bank Research, 2014, p. 8, (accessed on 10 $0^{\text {th }}$ July 2016), available at https://www.dbresearch.com/PROD/DBR_INTERNET_EN-

PROD/PROD0000000000340841/Recent+trends+in+FDI+activity+in+Europe\%3A+Regaining.PDF
} 
Commitment, it can be seen that the majority of such sectors are listed as "UNBOUND". Limited access to sectors such as legal, accounting or auditing will be granted to Vietnamese companies $^{22}$.

Table 3-6: The EU's top 10 restricted investment sectors (by average FRRI, 2010-2015)

\begin{tabular}{|c|l|c|}
\hline & \multicolumn{1}{|c|}{ Sector } & $\begin{array}{c}\text { Average FRRI } \\
(\mathbf{2 0 1 0 - 2 0 1 5 )}\end{array}$ \\
\hline 1 & Real estate investment & 0.285 \\
\hline 2 & Fisheries & 0.271 \\
\hline 3 & Air & 0.263 \\
\hline 4 & Legal & 0.238 \\
\hline 5 & Accounting \& audit & 0.22 \\
\hline 6 & Electricity generation & 0.203 \\
\hline 7 & Radio \& TV broadcasting & 0.191 \\
\hline 8 & Electricity & 0.191 \\
\hline 9 & Electricity distribution & 0.178 \\
\hline 10 & Maritime & 0.153 \\
\hline
\end{tabular}

Source: $O E C D$

Secondly, the volume of FDI inflows, shown in Table 3-4, indicates that there might be significant barriers to investment in Vietnam, compared to the EU. Recently, the developing countries, especially in the South East Asia, have been known as the growing destinations for $\mathrm{FDI}^{23}$. As a country in the South East Asia (SEA), Vietnam is gradually known as rather open to FDI because of the growing market, natural resources and export-oriented economy ${ }^{24}$. Thus, due to significant increase in FDI inflows for the recent years, it seems that Vietnam has generally liberalized investments into the country.

To conclude, trade in services and investments are among core chapters of the EU- Vietnam FTA. There is high potential for welfare gain from deep integration to the EU as Vietnam has committed to open up to investments in manufacturing of key sectors such as food and beverages, fertilizers and nitrogen composites, tires and tubes, gloves and plastic products, ceramics and construction materials. Vietnam also committed to remove restrictions on the assembly of marine engines, agricultural machinery, domestic appliances and bicycles ${ }^{25}$.

\footnotetext{
${ }^{22}$ EVFTA, Annex 8-a

${ }^{23}$ See note 21

${ }^{24}$ Sjoeholm, F. 'Foreign Direct Investments in Southeast Asia', IFN Working Paper, No.987, 2013, (accessed on $22^{\text {nd }}$ October 2016), available at http://www.ifn.se/wfiles/wp/wp987.pdf

${ }^{25}$ See note 2
} 
Moreover, for the EU services operators, Vietnam has committed to gradually improve access to many sectors such as business, environment, postal and courier, banking, insurance and maritime transportation. It is expected to be a crucial achievement for the EU enterprises as the access goes beyond both WTO commitments and any other FTAs Vietnam has concluded $^{26}$.

\section{Trade in Services}

Due to the constraint of available data, mutual trade in services between the EU and Vietnam were not statistically analysed. However, from European Commission Trade Division, the bilateral trade in services between the EU and Vietnam has been slightly increased over years.

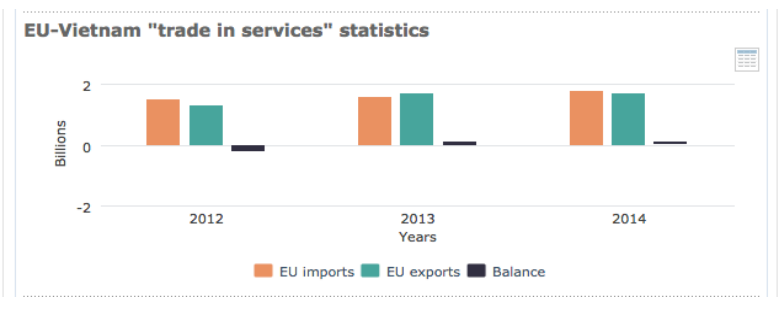

Source: European Commission

The reduction of barriers in trade in services is expected to provide a surge of investment inflow from the country benefitting liberalization. It reasons in the highprofitability of most services industries and in the economic structures of trade in services ${ }^{27}$. Investment inflow in services come along with market access restriction listed in the WTO schedule of commitments of each country as "mode 3 commercial presence" liberalization, very classic pattern of FDI. However, the WTO commitments of Vietnam do not allow the entrance of foreign services suppliers in most attractive sectors such as financial services, telecommunication, and transportation. The high quality of European services sectors would match with underdeveloped and highly closed services sector in Vietnam.

According to European Commission, Vietnam has gone well beyond its WTO and other FTAs commitments in many aspects. For example, Vietnam offered market access to many services sectors such as building cleaning services, packaging services, and trade fairs and exhibitions services. For higher education services, for

\footnotetext{
${ }^{26}$ See note 5

${ }^{27}$ Philip, J. et. al, "The Free Trade Agreement between Vietnam and the European Union: Quantitative and Qualitative Impact Analysis”, MUTRAP Report, October 2011, p.56, accessed on 10th January 2017, available at http://www.eurochamvn.org/sites/default/files/uploads/pdf/FTA9-\%20EU-VN\%20FTA\%20assessment.pdf
} 
the first time, Vietnam opened cross border services. In distribution services, Vietnam committed that after 5 years of the EVFTA enforcement, retailers will no longer have to undergo economic needs test (ENT) for opening outlets in Vietnam. Or as for financial services, Vietnam also committed on market access and national treatment cross border financial data processing and to advisory, intermediation and other securities related to trading for own account or for account of customers as long as they are permitted to Vietnam's own financial services suppliers.

\subsubsection{Non-tariff barriers to trade}

This section will focus on qualitative assessment of non-tariff barriers (NTBs) to trade. Due to the fact that there has not been any comprehensive database on NTBs, Market Access Database of the EU is used to have an overview on NTBs in Vietnamese market and the WTO Case Database is used to assesse the EU's market access.

Firstly, from the EU's Market Access Database, different measures are being applied on wide of sectors. Table 3-7 shows information on barriers to imports from the EU to Vietnamese market $^{28}$.

Table 3-7: Current barriers to the EU's imports to Vietnam

\begin{tabular}{|c|c|c|c|}
\hline No & Measures & Sectors & Barrier title \\
\hline 1 & Custom Procedure & Wines and Spirits & $\begin{array}{l}(*) \text { Restrictions on customs clearance for } \\
\text { wines and spirits, mobile phones and cosmetics }\end{array}$ \\
\hline 2 & Other NTMs & $\begin{array}{l}\text { Agriculture \& } \\
\text { Fisheries }\end{array}$ & $\begin{array}{l}(*) \text { Price controls on dairy and other type of } \\
\text { products }\end{array}$ \\
\hline 3 & IPR & Pharmaceuticals & $\begin{array}{l}\text { (*) Pharmaceuticals: Trading Rights \& Data } \\
\text { Exclusivity }\end{array}$ \\
\hline 4 & SPS & $\begin{array}{l}\text { Agriculture \& } \\
\text { Fisheries }\end{array}$ & (*) Ban on imported animal offal $^{*}$ \\
\hline 5 & Investment Related & Services & (*) Equity cap \\
\hline 6 & Trade in Services & $\begin{array}{l}\text { Distribution } \\
\text { Services }\end{array}$ & $\begin{array}{l}(*) \text { Economic Need Text for the distribution } \\
\text { sector }\end{array}$ \\
\hline 7 & Other NTMs & Other Industries & $\begin{array}{l}(*) \text { Non-deductibility of advertising and } \\
\text { promotional expenses }\end{array}$ \\
\hline 8 & $\begin{array}{l}\text { Government } \\
\text { Procurement }\end{array}$ & Horizontal & $\begin{array}{l}(*) \text { Preferential use of domestic materials in } \\
\text { public procurement }\end{array}$ \\
\hline
\end{tabular}

28 European Commission, Market Access Database, accessed on $10^{\text {th }}$ September 2016, available at: http://madb.europa.eu/madb/barriers_result.htm?redisplay=true\&measures=none\&sectors=none\&countries=VN \&d-49653-p=1 


\begin{tabular}{|c|l|l|l|}
\hline 9 & IPR & Other Industries & $(*)$ Protection of Intellectual Property Rights \\
\hline 10 & SPS & $\begin{array}{l}\text { Agriculture \& } \\
\text { Fisheries }\end{array}$ & $\begin{array}{l}\text { SPS import ban on animals and animal } \\
\text { products related to Bovine Spongiform } \\
\text { Encephalopathy (BSE) }\end{array}$ \\
\hline
\end{tabular}

Source: EU Market Access Barriers Database

$\left(^{*}\right)$ is to mark "key barrier" which is considered as trade barrier to be prioritized.

In general, SPS and IPRs are rather popular in Vietnam. Government Procurement and Custom \& Administrative Procedure are also listed. In addition to the EU Market Access Database, USTR's Market Access Barriers also confirms on different barriers to trade in Vietnam. Import bans in some products such as second-hand consumer goods or used spare parts for vehicles are still used in by Vietnam.

Looking into situations on market access of both economies, it can be said if such NTMs are covered under the EU-Vietnam FTA, there will be significant potential for welfare gains for the EU, compared to Vietnam.

\section{SPS \& TBT}

Firstly, as for SPS and TBT, they are measures being used commonly in many countries, not just in Vietnam and the EU. As from the recent announcement of EVFTA, different SPS and TBT related issues were put onto table to strengthen disciplines of WTO SPS and TBT agreement. SPS chapter of the agreement aimed at facilitating trade in plant and animal products. These provisions confirmed on the welfare for EU companies producing those animal products, underlying above information from EU Market Access Database. Also, both the EU and Vietnam agreed principles of regionalization and recognition of the EU as a single entity that helps promote trade facilitation between the two economies ${ }^{29}$.

Secondly, as for the TBT, Vietnam has agreed to engage international standards into its regulations. The EU companies producing wide range of commodities, including electrical appliances, IT, and food and beverages will get better access to Vietnamese market, under such provisions. There is also a specific annex addressing non-tariff barriers to automotive sector. Vietnam has committed to recognize the EU whole vehicle certificate of conformity, within 5 years after the enforcement of the agreement ${ }^{30}$. Additionally, Vietnam for the first time has accepted the marking of origin as "Made in EU” for non-agricultural products, except for pharmaceutical products.

\footnotetext{
${ }^{29}$ See note 2

${ }^{30}$ Ibid.
} 
Last but not least, the agreement also address provisions on custom \& administrative procedures, import and export licensing to facilitate trade between the EU and Vietnam, also to boost competitiveness of other suppliers.

\subsubsection{Intellectual Property Rights}

Under negotiation in the IPRs chapter, different forms of intellectual properties are covered such as geographical indicators, trademarks, copyrights, trade secret and patterns. IPRs are also mentioned as key barriers to trade of Vietnam's market.

Firstly, Vietnam is listed in 2013 Special 301 Report for widespread counterfeiting and privacy (2013 Watch List) ${ }^{31}$ of the United States. Vietnam has committed to a high level of protection, beyond the standards of WTO TRIPS agreement. The EU innovation, artworks and brands will therefore be better protected against being unlawfully copied ${ }^{32}$. Among main achievements of the FTA, Vietnam commits to accede to the WIPO Copyright Treaty and the WIPO Performances and Phonogram Treaty (known as "Internet Treaties"), which help to prevent authorised access to and use of creative works on the Internet or other digital networks ${ }^{33}$. Vietnam has promised to provide adequate legal protection and remedies against the circumvention of technology measures to protect holders' rights and to prohibit the deliberate alteration or deletion of electronic "rights management information". These commitments are expected to ensure that rights holders can effectively use technology to protect their rights and to license their work online.

Secondly, protecting European Geographical Indications is one of the significant achievements covered in the EVFTA. Geographical Indications are distinctive sigh used to identify a product, originating from a territory of a particular country or region where its quality reputation is linked to its geographical origin. Vietnam commits to protect 169 European foods and drink products from a specific geographical origin at a comparable level to that of the EU legislation. This means that products such as Champagne, Scotch whisky or Roquefort cheese will be reserved in Vietnam and Moc Chau tea, Buon Ma Thuot coffee on the other hand will be recognised as such in the EU. In general, farmers and businesses producing with traditional methods kinds of foods and drinks will benefit the most. These

\footnotetext{
31 The Special 301 Report identifies trade barriers to US companies, regarding the intellectual property law in other countries, with which the US has trade relationship. The Special 301 Report is announced annually by USTR under Section 301 as amended of the Trade Act 1974. The 2013 Special 301 Report is available at http://www.mpaa.org/wp-content/uploads/2014/02/2013-Special-301-Report.pdf

32 See note 2

${ }^{33}$ EVFTA, Chapter 12, Section B, Article 4.1
} 
protections will assure that Vietnam will be applied with appropriate administrative sanctions as soon as the FTA enters into force.

Last but not least, the EU pharmaceutical sector will benefit from improved data protection. With an important share of European exports to Vietnam (with approx. 8\% in 2015) ${ }^{34}$, pharmaceutical products are mentioned in a specific annex, in which both the EU and Vietnam agreed on provisions facilitating trade in these products. Vietnam will be considered as an attractive market for producers of pharmaceutical products, enable better access to quality medicine for the population. Vietnam commits to provide regulatory data protection to pharmaceutical, including agro-chemical products, for 5 years. Also, IPRs provisions will provide an extension of patent protection, up to 2 years, to compensate for delays in the marketing approval of pharmaceutical products if approval process takes more than 24 months. Additionally, Vietnam will withdraw existing clinical trials requirements on ethnicity that were not in line with international standards, especially those of the International Conference on Harmonisation odd Technical Requirements for Registration of Pharmaceutical for Human Use.

\subsubsection{Government Procurement}

Public procurement accounts for a substantial share of world trade flows and it has been considered as a main topic for new-generation trade agreement. In the EU, public purchase of goods and services is estimated to contribute to $16 \%$ of $\mathrm{GDP}^{35}$. On the other hand, Vietnam is among the countries with highest ratio of public investment to GDP worldwide, maintaining at around 15\% since 1995 with large part invested in infrastructure ${ }^{36}$. Therefore, Vietnamese market of public sectors has been very attractive to the EU that makes Government Procurement an important chapter of the EVFTA. Within the EVFTA, the EU and Vietnam have agreed on disciplines inline with the WTO Government Procurement Agreement (GPA). It is expected to create potential welfare gains for both, as Vietnam is not yet member of the GPA, only as the observer. According to the EU, the government chapter of the EVFTA achieves a certain level of transparency and procedural fairness that are comparable to other FTAs of the EU and other developed and more advanced developing countries ${ }^{37}$. The EU

\footnotetext{
${ }^{34}$ See note 2, p.30

${ }^{35}$ See note 2, p.57

36 Ibid.

${ }^{37}$ See note 5
} 
businesses will be the first foreign companies to get that level of access to Vietnamese procurement market ${ }^{38}$.

The overview of Vietnamese thresholds (in $\mathrm{SDR}^{39}$ ) and coverage in the EVFTA is illustrated in the Table 3-9.

Table 3-9: Vietnamese thresholds (in SDR) and coverage in the EVFTA ${ }^{40}$

\begin{tabular}{|c|c|c|c|c|c|c|}
\hline & \multicolumn{2}{|c|}{$\begin{array}{c}\text { Section A: } \\
\text { Central Level of } \\
\text { Government Entities }\end{array}$} & \multicolumn{2}{|c|}{$\begin{array}{c}\text { Section B: } \\
\text { Sub-Central level of } \\
\text { Government Entities }\end{array}$} & \multicolumn{2}{|c|}{$\begin{array}{c}\text { Section C: } \\
\text { Other covered entities }\end{array}$} \\
\hline & $\begin{array}{l}\text { All ministrie } \\
\text { office and } \mathrm{t} \\
\text { equivalen }\end{array}$ & $\begin{array}{l}\text { ocial security } \\
\text { other entities } \\
\text { ministries }\end{array}$ & $\begin{array}{r}\text { Two } \mathrm{n} \\
\text { Hanoi and } \mathrm{H}\end{array}$ & $\begin{array}{l}\text { r cities: } \\
\text { Chi Minh city }\end{array}$ & $\begin{array}{r}\text { Two utilit } \\
\text { owned Enter } \\
\text { universiti } \\
\text { research in } \\
\text { publi }\end{array}$ & $\begin{array}{l}\text { lated State } \\
\text { es; two major } \\
\text { two major } \\
\text { utes and } 34 \\
\text { spitals }\end{array}$ \\
\hline & $\begin{array}{c}\text { Goods and } \\
\text { services }\end{array}$ & $\begin{array}{c}\text { Construction } \\
\text { services }\end{array}$ & $\begin{array}{c}\text { Goods and } \\
\text { services }\end{array}$ & $\begin{array}{c}\text { Construction } \\
\text { services }\end{array}$ & $\begin{array}{c}\text { Goods and } \\
\text { services }\end{array}$ & $\begin{array}{c}\text { Construction } \\
\text { services }\end{array}$ \\
\hline $\begin{array}{l}\text { At entry into } \\
\text { force }\end{array}$ & $1,500,000$ & $40,000,000$ & $3,000,000$ & $40,000,000$ & $3,000,000$ & $40,000,000$ \\
\hline $\begin{array}{l}\text { After } \\
\text { transition } \\
\text { period of } 15 \\
\text { years }\end{array}$ & 130,000 & $5,000,000$ & $1,000,000$ & $15,000,000$ & $1,000,000$ & $15,000,000$ \\
\hline
\end{tabular}

Firstly, in term of market access, the EU companies will be able to bid for public contracts with Vietnamese companies for (i) Vietnamese ministries at central level, including infrastructure such as roads and ports, and two ministry equivalent entities (Committee on Ethnic Minority Affairs and Government Inspectorate), (ii) Two important state-owned enterprises which are Electricity of Vietnam (EVN) and Vietnam Railway (VNR), (iii) 34 public hospitals directly under the administration of the Ministry of Health, (iv) two major universities, and (v) two major cities, Hanoi and Ho Chi Minh City, which stand for $50 \%$ of procurement at sub-central level ${ }^{41}$.

Secondly, as for goods procurement, Vietnam offers a large coverage of products, except several agricultural products. It is worth noted that all pharmaceutical products purchased by the Ministry of Health, or public hospitals and Hanoi and Ho Chi Minh city’s Department of

\footnotetext{
${ }^{38}$ See note 5

${ }^{39}$ SDR - Special Drawing Rights are supplementary foreign exchange reserve assets defined and maintained by the International Monetary Fund (IMF).

${ }^{40}$ EVFTA, Annex 9-c

${ }^{41}$ Ibid.
} 
Health, are covered in the EVFTA. A specific scheme for pharmaceutical products has been agree in the specific annex. Vietnam may set aside scheme as below:

Table 3-8: Respective Percentage of contract value of pharmaceutical products ${ }^{42}$

\begin{tabular}{|c|c|c|c|c|}
\hline Year & $1^{\text {st }}-2^{\text {nd }}$ & $3^{\text {rd }}-9^{\text {th }}$ & $10^{\text {th }}-15^{\text {th }}$ & $16^{\text {th }}$ onward \\
\hline $\begin{array}{l}\text { Percentage of } \\
\text { contract value }\end{array}$ & 100 & 65 & 60 & 50 \\
\hline
\end{tabular}

After the transitional period of two years from enforcement of the agreement, EU suppliers will have legally secured market access into Vietnam. The share of domestic suppliers will be diminished over 15 years to the final share of $50 \%$. The remainder will be open to all producers with market access rights.

Finally, Vietnam offers a number of service sectors, including majority of computer-related services. For public works, Vietnam commits to offer basically all construction services, including under the Ministry of Transport and notably to include dredging services, which are important for many EU member states ${ }^{43}$.

\subsubsection{Other trade-related issues}

\section{Trade and Sustainable Development}

Topics for Sustainable Development have been covered in many new generation agreements. The EU aims to ensure that trade policy supports sustainable development, within not only the EU but also with its partners countries. Therefore, a comprehensive chapter on Sustainable Development of the EVFTA aims at (i) promoting mutual supportiveness between trade and investment, labour and environmental issues and (ii) ensuring that increased trade and investment do not threat to labour and environmental protection.

Firstly, as for labour matters, core labour standards of the International Labour Organization (ILO) were addressed with specific commitments. They are (i) freedom of association, (ii) forced or compulsory labour, (iii) child labour and (iv) non-discrimination in respect of employment and occupation.

Secondly, on the environment, the EVFTA includes commitments to effective implementation by each country of the UN Convention on Biological Diversity (CBD), the UN Convention on International Trade in Endangered Species (CITES) and the UN Framework Convention on Climate Change (UNFCCC). Also, there is a dedicated article on climate change that

\footnotetext{
${ }^{42}$ See note 2, p.30

${ }^{43}$ Ibid.
} 
underlines common commitments of both the EU and Vietnam to achieve climate change objectives.

Thirdly, there is specific attention to trade and investment practices for fostering sustainable development, including fair and ethical trade and other voluntary sustainable schemes from where international principles and OECD guidelines on responsible business conduct are made. Furthermore, there will be a special Committee on Trade and Sustainable Development to specifically monitor the implementation of Trade and Sustainable Development provisions $^{44}$. At domestic level, each country will consult with Domestic Advisory Groups (DAGs) to comprise independent civil society representatives and to include employers and workers' organisations, business groups and environmental organisations ${ }^{45}$.

Last but not least, the EVFTA includes a special annex, the Green Tech Annex ${ }^{46}$, on nontariff barriers affecting the renewable energy. The annex contains specific rules for the renewable energy sector, focusing on the use of international standards in such sector. The Annex is expected to bring benefits for both countries when trade and investment in renewable energy sector are fostered. Such commitment will help to boost the EU's investment in such sector into Vietnam and in return, Vietnam will profit from the EU's know-how and rely on the EU's considerable in this sector.

\section{Competition Policy and State-Owned Enterprises}

Competition policy is also a particular interest to both side of the EVFTA because anticompetition behaviour and subsidies are behind-the-border barriers. Ensuring a common level of playing ground for both European and Vietnamese companies will help to allocate scarce resources.

Firstly, the EU and Vietnam have agreed on the obligation to maintain competition laws and relevant authorities to apply the law in a transparent and non-discriminatory manner. Companies operating in Vietnam should respect the same competition principles as in the EU. On the other hand, they have the rights to be respected in the competition procedures and they can ask Vietnamese authorities to ensure an efficient competitive environment.

Secondly, the EVFTA points out certain kinds of subsidies that can hinder competition and trade. Both economies therefore agreed to limit the potential negative effects of the subsidies. Both the EU and Vietnam have achieved to levelling the playgrounds for companies of the

\footnotetext{
${ }^{44}$ EVFTA, Chapter 15, Art.5

45 Ibid.

46 'EU and Vietnam hold fifth round of negotiations for a free trade agreement', European Commission, 2013, accessed on $12^{\text {th }}$ October 2016, available at: http://trade.ec.europa.eu/doclib/press/index.cfm?id=984
} 
two ${ }^{47}$. Vietnam agrees to notify not only subsidies to goods but also to services. This commitment is beyond the WTO rules.

(i) Enterprises of both economies have opportunities to alert their governments to potential subsidies with negative effects for their business. The Government then will act on their behalf to consult with other party of the FTA to get information and further to find a satisfactory solution.

(ii) Unlimited guarantees are not allowed and subsidies to ailing companies are not possible without a viable restructuring plan.

(iii) Both countries can provide aid to public services and continue to subsiding services of general economic interest.

\subsection{Conclusion on expected deep integration effects}

After having provided analysis on quantitative and qualitative perspectives for deep integration, main conclusions on welfare effects are drawn.

Firstly, looking at quantitative indicators, low intra-industry trade between the EU and Vietnam can promote further specialization between the two and large welfare gains then will be followed. Moreover, as for the RMA values, the two economies seem not to face significant barriers to their bilateral trade. Also, the removal of NTBs will expect better potential for trade between the EU and Vietnam.

Secondly, as looking into qualitative analysis, different measures in NTBs were found in different sectors, naming at agricultural and fishery products, pharmaceutical products or services. This research found that structural issues relating to FDI attraction is revealed. IPRs also bring certain concerns for the EU due to importation of counterfeited products in Vietnam. Competition policy related to FDI and services are also considered as importation to bilateral trade between two economies. Also, trade related issues of sustainable development are significant important to promote trade between the EU and Vietnam.

As the result, with detailed analysis on different regulatory barriers that are included in the EVFTA, it is clear that the EVFTA would lead to enormous welfare enhancement to both countries. With more complete market development and trade liberalization, the EU seems to gains better because it market access to the Vietnamese market will be more significant. In order for Vietnam to gain significant welfare, the country has to gradually improve its

\footnotetext{
${ }^{47}$ See note 2
} 
domestic market level. From regional perspective, Vietnam can totally gain from welfare effects with deeper integration into similar market countries in the EU. 
CHAPTER 4: OPPORTUNITIES, CHALLENGES AND RECOMMENDATIONS FOR VIETNAM

From above results of shallow and deep integration of EVFTA, there are some conclusions drawn on opportunities and challenges for Vietnam. Based on that, this section will be followed with some recommendations for Vietnam on the enforcement of the EVFTA.

\subsection{Opportunities for Vietnam}

Firstly, from the data on trade between Vietnam and the EU, it can be seen that EVFTA would be essential to boost exports from Vietnam to the EU. The EVFTA will confirm and maintain the importance of the EU's market to Vietnam's exports, among top exports' destinations. The EU's large size of market, accounting for 500 million consumers and 21 million small and medium-sized enterprises (SMEs) ${ }^{48}$ will benefit Vietnamese exports in many key sectors such as footwear, agricultural products or electrical machine parts. The EU's market to all 28 state members will be opened to Vietnam, and also of markets of countries with which the EU currently has FTAs. Confirming with the above result on the bilateral intra-industry trade between the EU and Vietnam, the FTA will also be beneficial for products from Vietnam, especially key product sectors.

Secondly, the EVFTA will be significant momentum for the EU's FDI inflows to Vietnam. Potential welfare gains from liberalization on the assembly of marine engines and agricultural machinery will create opportunities for Vietnam to access advanced technology from the EU. The EU has significant comparative advantages in aircraft and automobile industries; the EVFTA will bridge technological know-how from the EU to Vietnam and help to accelerate the industrialization and modernization of Vietnam. According to the Delegation of the European Union to Vietnam, electricity production and manufacturing sector are among the most prominent sectors for EU investors. There have been 590 manufacturing projects, accounting for 6.62 billion USD and 19 projects in electricity production and transmission, accounting for 3.54 billion USD by EU investors in Vietnam.

Last but not least, the EVFTA is the new generation agreement with many beyond-trade issues to be addressed. Vietnam has committed to liberalize trade in different aspects such as NTBs, intellectual property rights, government procurement and sustainable developments. These commitments will contribute into country’s trade policy reform. By participating in the

\footnotetext{
48 'The European Single Market', European Commission, accessed on $12^{\text {th }}$ October 2016, available at https://ec.europa.eu/growth/single-market_en
} 
EVFTA, Vietnam will have to peacefully resolve its policies to align with commitments in the EVFTA.

\subsection{Challenges for Vietnam}

Beside opportunities, the EVFTA will also pose different challenges for Vietnam.

Firstly, the EVFTA challenges Vietnam in maintaining competitiveness of Vietnamese products. Beside an FTA with Vietnam, the EU is currently negotiating FTAs with many Asian countries, especially ASEAN countries like Thailand, Malaysia, the Philippines and Indonesia. These countries have similar exporting patterns with Vietnam and can compete with Vietnam. Also, if the TTIP is going to be concluded in the far future, Vietnam may face problems in exporting to the EU.

Secondly, many products that Vietnam mainly exports to the EU are under categories of which tariffs will be slowly reduced over long period of time. Vietnam, therefore, may not be able to increase the exports to competitive products from other countries quickly enough to occupy the EU markets. After the certain period of time, Vietnam might lose the welfare as the loss of competitiveness in the EU's market as well as domestic industries. Also, Vietnam might also have to face strong pressure from the EU on trade in services. The EU's firms with experiences in management and quality will bring great challenges for Vietnamese enterprises, especially logistic industry, seaports or financial services.

Last but not least, the issues of NTBs will be significant challenges for Vietnamese enterprises. The increases of export volume arising from low tariffs might lead to more NTMs to be applied. Also, as the majority proportion of Vietnamese exports to the EU includes agricultural products and labour-intensive produces, it is very likely that the regulations on environment or labour will be applied against Vietnamese products into the EU. Therefore, it is important for Vietnamese enterprises to increase the share of processed and high-value added products, as well as apply better management practices to meet standards and requirements of the EU markets.

\subsection{Recommendations for Vietnam}

Based on above analysis, some recommendations are suggested for Vietnam to take opportunities and to overcome challenges from the enforcement of the EVFTA.

Firstly, Vietnamese firms should take advantages of European technology know-how to improve the quality of products and to increase exportations of higher-value added products. By doing so, Vietnamese firms can maintain competitiveness within the EU markets and also 
to avoid NTMs. Vietnamese government can support the amelioration of enterprises competitiveness by calling the EU corporations into establishing joint ventures or $100 \%$ foreign-invested enterprises in Vietnam. Through that mechanism, advanced technologies as well as managing experiences will be transferred to Vietnamese companies. Also, from those experiences, the EVFTA will help to upgrade Vietnamese standards from the EU's institutions.

Secondly, the EU is the mega market with combination of 28 country markets. Beside traditional markets such as France, Germany, etc., Vietnamese enterprises should explore new markets within the EU to reduce dependence on traditional markets. Also, different market the EU has different favourites in certain products; Vietnamese enterprises should also explore new products to those markets.

Thirdly, to support businesses with better preparations for the implementation of the EVFTA, the government should implement better mechanisms to equip firms with understanding about the EVFTA, education and propaganda on the EU market information such as quality standards, labour or environmental requirements. Different contacts between the government and public through activities such as training workshops, seminars or dialogue conferences to introduce about the EVFTA to different community groups should be implemented. Those activities will be useful channels to prepare businesses with better capacity to improve quality and value of products, better capacity to fight against different NTBs, and to revise domestic policies to further support exporting enterprises.

Last but not least, the reform of Vietnamese current legislation system is also an important step toward the EVFTA. Vietnam should take advantages from the EU's commitments to support Vietnam technically into the implementation of the FTA. 


\section{CONCLUSIONS}

This research focuses on the expected welfare effects of the recently concluded free trade agreement between the EU and Vietnam, basing on the guidelines of the Sussex Framework. At first, the study provides analysis on potential trade creation and trade diversion created from shallow integration, using statistical data on trade in goods. The results of shallow integration analysis shows that Vietnam might gain potentially from the FTA due to the breakdown of tariffs, the natural trading partners as the EU is among the main export destinations of Vietnam. On the other hand, the welfare gains might be more limited to the EU than to Vietnam due to dissimilarity in production patterns, non-natural trading partners of Vietnam to the EU.

Secondly, the research studies the potential for welfare gains from deep integration from using both quantitative and qualitative analysis. The quantitative analysis shows that the two economies seem not to face significant barriers to their bilateral trade. The removal of NTBs therefore will expect better potential for trade between the EU and Vietnam. Also, by looking into qualitative analysis, different measures of NTBs were pointed, especially in agricultural and fishery sectors, pharmaceutical sector or services. However, potential for welfare gains will likely be enormous from deep integration due to the commitments of both economies in IPRs, FDI policy or other trade related issues such as sustainable development. With higher level of market development and trade liberalization, the EU seems to gain more significantly than to Vietnam.

In order for Vietnam to enhance welfare gains from the integration, there has been analysis on opportunities and challenges for Vietnam, followed by policy recommendations. Vietnamese government is expected to support firms with understanding about the EVFTA, market information on quality standards, labour and environmental requirements, building capacity to improve quality and value of exporting products. Also, revision of domestic policies is also recommended for Vietnam to further support domestic enterprises not only to promote exports to the EU, but also to enhance competitiveness of enterprises in the domestic market as the future entrance of EU enterprises to Vietnam. In term of enterprises, Vietnamese enterprises are recommended to improve the quality of products so as to align with higher standards of the EU market so as to increase exports of higher value-added products and also to avoid NTMs. Also, Vietnamese enterprises are suggested to explore new market within the EU as Vietnam will enjoy duty-free quota-free access to the 28 member states of the EU and also markets with which the EU has already had agreements.

In conclusion, it can be said that the EVFTA could lead to interest of both economies. 


\section{LIST OF REFERENCES}

Evan, D. et al., 'Assessing Preferential Trading Agreements Using the Sussex Framework', CARIS Working Paper, 2007, No.01, (accessed on $1^{\text {st }}$ April 2016), available at https://www.sussex.ac.uk/webteam/gateway/file.php?name =cariswp01.pdf\&site=261

European Commission, Market Access Database, (accessed on 10 ${ }^{\text {th }}$ September 2016), available at: http://madb.europa.eu/madb/barriers_result.htm?redisplay=true\&measures=none\&sectors=no ne\&countries $=$ VN\&d-49653-p=1

'EU and Vietnam hold fifth round of negotiations for a free trade agreement', European Commission, 2013, (accessed on $12^{\text {th }}$ October 2016), available at: http://trade.ec.europa.eu/doclib/press/index.cfm?id=984

EU-Vietnam Free Trade Agreement, European Union - Vietnam, Agreed Texted as of January 2016

'Facts and figures: Free Trade Agreement between EU and Vietnam', European Commission Fact Sheet, 2015, (accessed $15^{\text {th }}$ April 2016), http://europa.eu/rapid/press-release_MEMO-155468_en.htm

Finger, J.M. \& Kreinin, M.E. 'A Measure of 'Export Similarity' and its possible use', Economic Journal, 89, 1979, pp.905-912

Gasiorek, M. et al., 'Qualitative Analysis of a potential Free Trade Agreement between the European Union and India', Main Report, Centre for the Analysis of Regional Integration at Sussex, 2007 
'Guide to the EU-Vietnam Free Trade Agreement', Delegation of the European Union to Vietnam, 2016, $\quad$ (accessed $12^{\text {th }}$ April 2016), https://eeas.europa.eu/delegations/vietnam/documents/eu_vietnam/evfta_guide.pdf

Organisation for Economic Co-operation and Development (OECD), Foreign Direct Investment for Development - Maximising Benefits, Minimising Costs, OECD Secretariat: France, 2002, p.12, (accessed on $10^{\text {th }}$ July 2016), available at https://www.oecd.org/investment/investmentfordevelopment/1959815.pdf

Philip, J. et. al, “The Free Trade Agreement between Vietnam and the European Union: Quantitative and Qualitative Impact Analysis”, MUTRAP Report, October 2011, p.56, accessed on 10th January 2017, available at http://www.eurochamvn.org/sites/default/files/uploads/pdf/FTA9-\%20EUVN\%20FTA\%20assessment.pdf

Rollo, J. 'Potential Effects of the Proposed Transatlantic Trade and Investment Partnership on Selected Developing Countries', Report Paper, CARIS, p.67, (accessed on $10^{\text {th }}$ July 2016), available at https://www.gov.uk/dfid-research-outputs/potential-effects-of-the-proposedtransatlantic-trade-and-investment-partnership-on-selected-developing-countries

Shelburne, R. \& Jorge, G. 'The Role of Intra-Industry Trade in Service Sector', in Plummer, M. (ed.) Empirical Methods in International Trade: Essays in Honour Mordechai Kreinin, Edward Elgar Press, 2004, pp.110-128

Sjoeholm, F. 'Foreign Direct Investments in Southeast Asia', IFN Working Paper, No.987, 2013, (accessed on $22^{\text {nd }}$ October 2016), available at http://www.ifn.se/wfiles/wp/wp987.pdf

'The European Single Market', European Commission, (accessed on $12^{\text {th }}$ October 2016), available at https://ec.europa.eu/growth/single-market_en 
'Trans-Pacific Partnership Leaders Statement', United States Trade Representative, 2011 (accessed 10 $0^{\text {th }}$ July 2016), available at https:/ustr.gov/about-us/policy-offices/pressoffice/press-releases/2011/november/trans-pacific-partnership-leaders-statement

World Trade Organization, A Practical Guide to Trade Policy Analysis, WTO: Geneva, 2012

United Nations Conference on Trade and Development (UNCTAD), 'Module 5 - Practical regional trade analysis: Using international databases to analyse Regional Trade Agreements', Teaching Material on Regional Trade Agreements, 2010

Vetter, S., 'Recent Trends in FDI Activity in Europe - Regaining lost ground to accelerate growth', Deustche Bank Research, 2014, p. 8, (accessed on $10^{\text {th }}$ July 2016), available at https://www.dbresearch.com/PROD/DBR_INTERNET_EN-

PROD/PROD0000000000340841/Recent+trends+in+FDI+activity+in+Europe\%3A+Regainin g.PDF 
ANNEXES

\section{ANNEX A}

\section{List of country codes, as used in WITS System}

$\begin{array}{ll}\text { CHE } & \text { Switzerland } \\ \text { CHN } & \text { China } \\ \text { EU } & \text { European Union } \\ \text { JPN } & \text { Japan } \\ \text { KOR } & \text { Korea, Republic } \\ \text { NOR } & \text { Norway } \\ \text { OAS } & \text { Other Asia, nes }{ }^{49} \\ \text { ROW } & \text { Rest of the world } \\ \text { RUS } & \text { Russia Federation } \\ \text { TUR } & \text { Turkey } \\ \text { USA } & \text { United States }\end{array}$

\footnotetext{
${ }^{49}$ As from WITS, Taiwan, China is disseminated as “Other Asia, nes“ (artificial country code OAS)
} 
ANNEX B

Figure 2-3: Applied tariffs of the EU on imports from Vietnam by product (2014, Simple Average, HS 2-digit level)

Applied tariff of the EU on imports from Vietnam by product 2014, Simple Average, HS 2-digit level

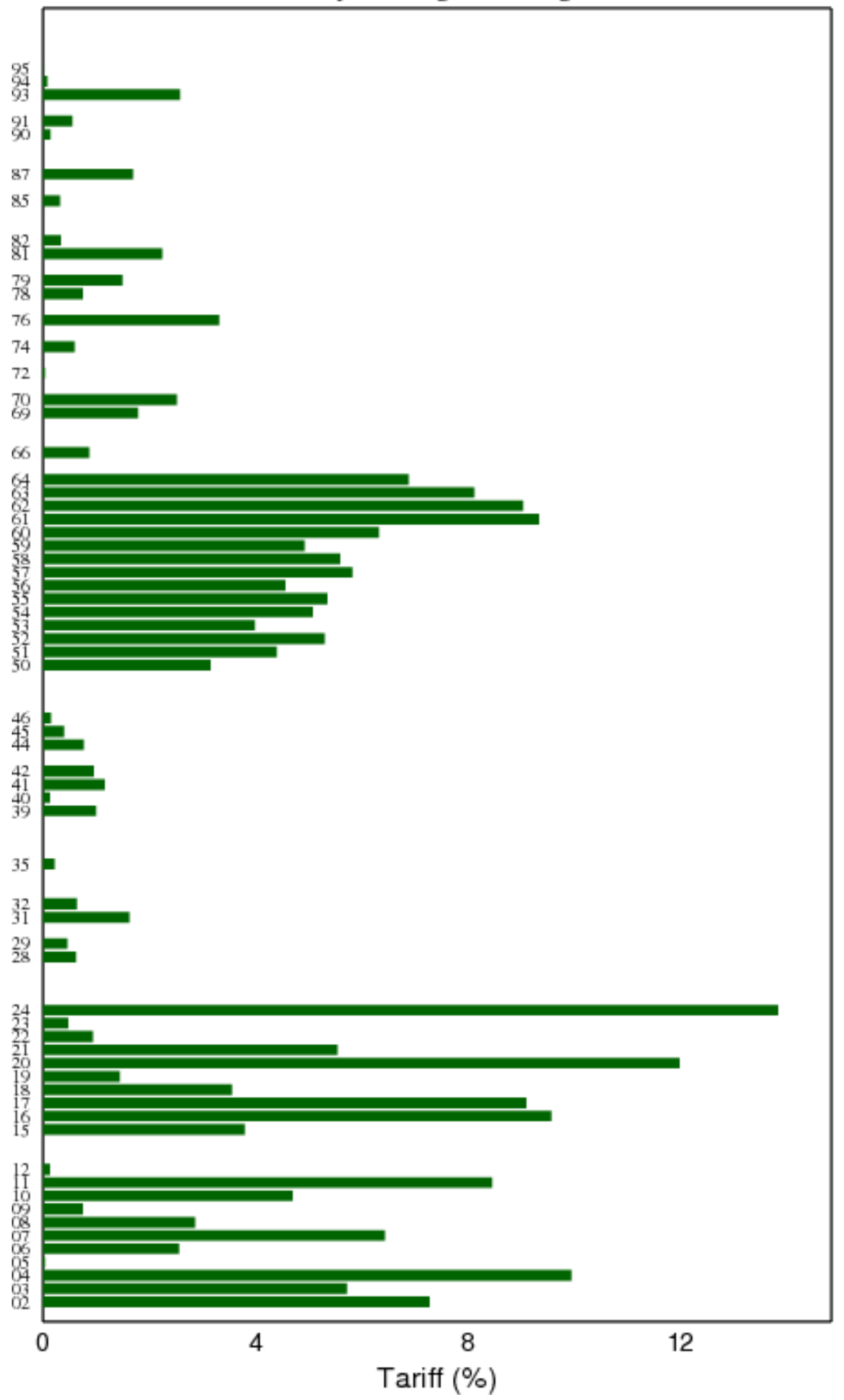


Figure 2-4: Applied tariffs of Vietnam on imports from the EU by product (2014, Simple Average, HS 2-digit level)

Applied tariff of Vietnam on imports from the EU by product 2014, Simple Average, HS 2-digit level

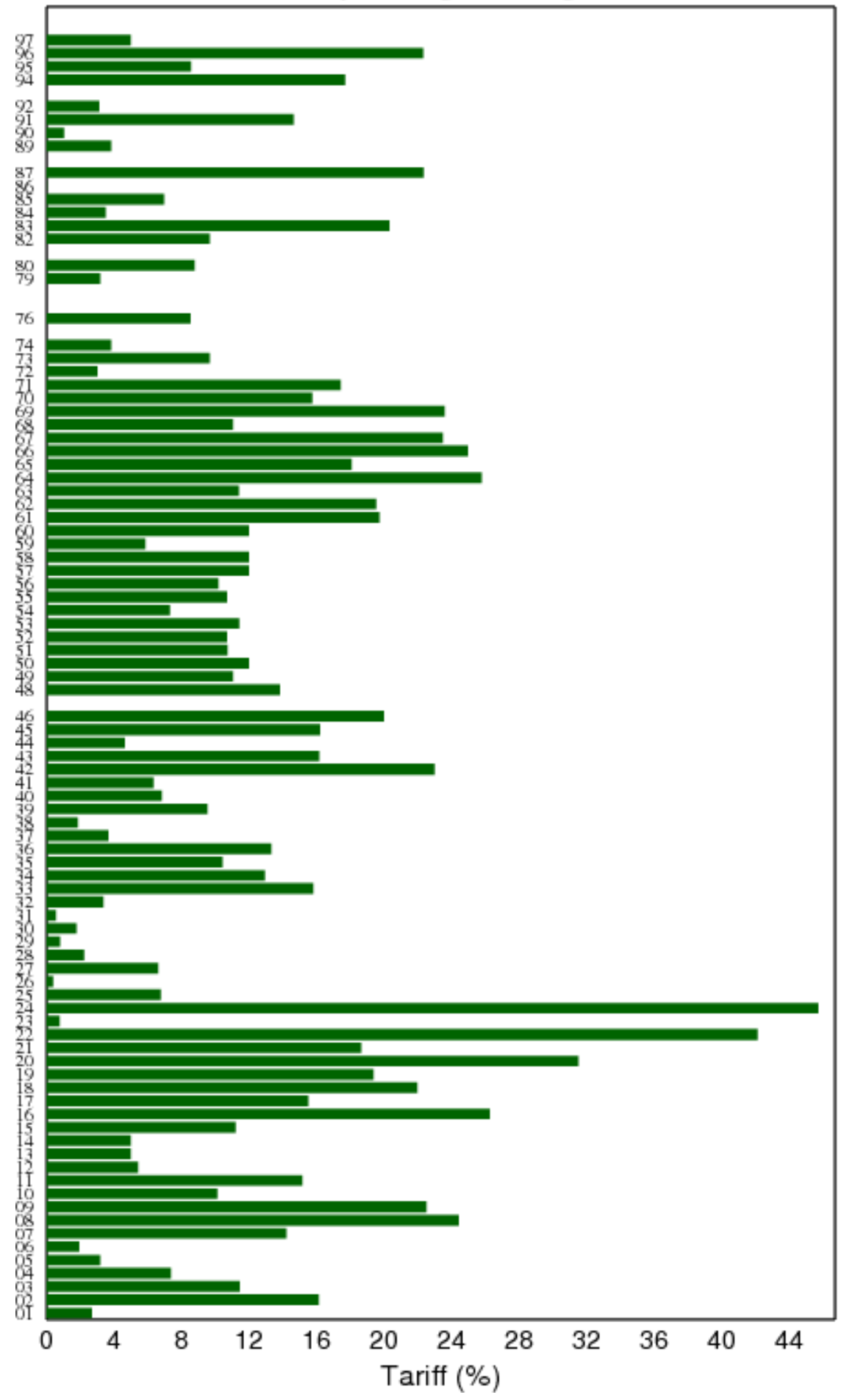


ANNEX C

Table 2-13: RCAs for the top 15 exporting products of the EU (2014) - HS 4-digit

\begin{tabular}{|c|c|c|c|c|c|c|c|}
\hline No & Country & $\begin{array}{l}\text { Product } \\
\text { Code }\end{array}$ & Product Name & $\begin{array}{c}\text { Value } \\
\text { (1000USD) }\end{array}$ & Shares & $\begin{array}{l}\text { World } \\
\text { Shares }\end{array}$ & RCA \\
\hline 1 & The EU & 8703 & $\begin{array}{l}\text { Motor cars and other motor vehicles; principally } \\
\text { designed for the transport of persons, including } \\
\text { station wagons and racing cars }\end{array}$ & 152887089.3 & $6.96 \%$ & $3.65 \%$ & 1.91 \\
\hline 2 & The EU & 2710 & $\begin{array}{l}\text { Coal; briquettes, ovoid and similar solid fuels } \\
\text { manufactured from coal }\end{array}$ & 115204151.1 & $5.24 \%$ & $5.57 \%$ & 0.94 \\
\hline 3 & The EU & 3004 & $\begin{array}{l}\text { Medicaments; consisting of mixed or unmixed } \\
\text { products for therapeutic or prophylactic use, put } \\
\text { up in measured doses or packed for retail sale }\end{array}$ & 103955114.9 & $4.73 \%$ & $1.54 \%$ & 3.07 \\
\hline 4 & The EU & 8802 & $\begin{array}{l}\text { Aircraft n.e.c. in heading no. 8801; spacecraft } \\
\text { (including satellites) and suborbital and } \\
\text { spacecraft launch vehicles }\end{array}$ & 55610305.03 & $2.53 \%$ & $0.44 \%$ & 5.71 \\
\hline 5 & The EU & 8708 & $\begin{array}{l}\text { Motor vehicles; parts and accessories, of } \\
\text { heading no. } 8701 \text { to } 8705\end{array}$ & 52425997.25 & $2.39 \%$ & $2.12 \%$ & 1.13 \\
\hline 6 & The EU & 7108 & $\begin{array}{l}\text { Gold (including gold plated with platinum) } \\
\text { unwrought or in semi-manufactured forms, or in } \\
\text { powder form }\end{array}$ & 46422306.03 & $2.11 \%$ & $1.39 \%$ & 1.53 \\
\hline 7 & The EU & 8411 & $\begin{array}{l}\text { Turbo-jets, turbo-propellers and other gas } \\
\text { turbines }\end{array}$ & 42197697.83 & $1.92 \%$ & $0.34 \%$ & 5.63 \\
\hline 8 & The EU & 3002 & $\begin{array}{l}\text { Human blood; animal blood for therapeutic, } \\
\text { prophylactic or diagnostic uses; antisera, other } \\
\text { blood fractions, immunological products, } \\
\text { modified or obtained by biotechnological } \\
\text { processes; vaccines, toxins, cultures of micro- } \\
\text { organisms (excluding yeasts) etc. }\end{array}$ & 35236320.54 & $1.60 \%$ & $0.61 \%$ & 2.64 \\
\hline 9 & The EU & 8803 & Aircraft; parts of heading no. 8801 or 8802 & 23644369.92 & $1.08 \%$ & $0.37 \%$ & 2.92 \\
\hline 10 & The EU & 9018 & $\begin{array}{l}\text { Instruments and appliances used in medical, } \\
\text { surgical, dental or veterinary sciences, including } \\
\text { scintigraphic apparatus, other electro-medical } \\
\text { apparatus and sight testing instruments }\end{array}$ & 22963534.07 & $1.05 \%$ & $0.55 \%$ & 1.91 \\
\hline 11 & The EU & 8479 & $\begin{array}{l}\text { Machinery and mechanical appliances; having } \\
\text { individual functions, n.e.c. in this chapter }\end{array}$ & 22264658.64 & $1.01 \%$ & $0.41 \%$ & 2.46 \\
\hline 12 & The EU & 8481 & $\begin{array}{l}\text { Taps, cocks, valves and similar appliances for } \\
\text { pipes, boiler shells, tanks, vats or the like, } \\
\text { including pressure-reducing valves and } \\
\text { thermostatically controlled valves }\end{array}$ & 21869105.94 & $1.00 \%$ & $0.45 \%$ & 2.22 \\
\hline 13 & The EU & 8471 & $\begin{array}{l}\text { Automatic data processing machines and units } \\
\text { thereof, magnetic or optical readers, machines } \\
\text { for transcribing data onto data media in coded } \\
\text { form and machines for processing such data, not } \\
\text { elsewhere specified or included }\end{array}$ & 21470541.49 & $0.98 \%$ & $2.32 \%$ & 0.42 \\
\hline 14 & The EU & 7102 & $\begin{array}{l}\text { Diamonds, whether or not worked, but not } \\
\text { mounted or set }\end{array}$ & 20638507.57 & $0.94 \%$ & $0.53 \%$ & 1.77 \\
\hline 15 & The EU & 8517 & $\begin{array}{l}\text { Telephone sets, including telephones for cellular } \\
\text { networks or for other wireless networks; other } \\
\text { apparatus for the transmission or reception of } \\
\text { voice, images or other data }\end{array}$ & 19047392.2 & $0.87 \%$ & $1.20 \%$ & 0.73 \\
\hline & Total & & & & $34.41 \%$ & $21.49 \%$ & \\
\hline & Average & & & & & & 2.33 \\
\hline
\end{tabular}


Table 2-14: RCAs for the top 15 exporting products of Vietnam (2014) - HS 4-digit

\begin{tabular}{|c|c|c|c|c|c|c|c|}
\hline No & Country & $\begin{array}{c}\text { Product } \\
\text { Code }\end{array}$ & Product Name & $\begin{array}{c}\text { Value } \\
\text { (1000USD) }\end{array}$ & Shares & $\begin{array}{l}\text { World } \\
\text { Shares }\end{array}$ & RCA \\
\hline 1 & Vietnam & 8525 & $\begin{array}{l}\text { Transmission apparatus for radio-broadcasting or } \\
\text { television, whether or not incorporating reception } \\
\text { apparatus or sound recording or reproducing } \\
\text { apparatus; television cameras, digital cameras and } \\
\text { video camera recorders. }\end{array}$ & 21749186.02 & $14.53 \%$ & $1.27 \%$ & 11.4 \\
\hline 2 & Vietnam & 2709 & $\begin{array}{l}\text { Petroleum oils and oils obtained from bituminous } \\
\text { minerals; crude }\end{array}$ & 7224230.188 & $4.83 \%$ & $7.42 \%$ & 0.65 \\
\hline 3 & Vietnam & 8471 & $\begin{array}{l}\text { Automatic data processing machines and units } \\
\text { thereof, magnetic or optical readers, machines for } \\
\text { transcribing data onto data media in coded form and } \\
\text { machines for processing such data, not elsewhere } \\
\text { specified or included }\end{array}$ & 6099109.085 & $4.08 \%$ & $2.12 \%$ & 1.92 \\
\hline 4 & Vietnam & 6403 & $\begin{array}{l}\text { Footwear; with outer soles of rubber, plastics, } \\
\text { leather or composition leather and uppers of leather }\end{array}$ & 4290750.264 & $2.87 \%$ & $0.30 \%$ & 9.67 \\
\hline 5 & Vietnam & 6404 & $\begin{array}{l}\text { Footwear; with outer soles of rubber, plastics, } \\
\text { leather or composition leather and uppers of textile } \\
\text { materials }\end{array}$ & 3667128.874 & $2.45 \%$ & $0.13 \%$ & 18.77 \\
\hline 6 & Vietnam & 9403 & Furniture and parts thereof, n.e.c. in chapter 94 & 3430547.232 & $2.29 \%$ & $0.48 \%$ & 4.78 \\
\hline 7 & Vietnam & 901 & $\begin{array}{l}\text { Coffee, whether or not roasted or decaffeinated; } \\
\text { husks and skins; coffee substitutes containing coffee } \\
\text { in any proportion }\end{array}$ & 3311395.619 & $2.21 \%$ & $0.17 \%$ & 13.25 \\
\hline 8 & Vietnam & 8517 & $\begin{array}{l}\text { Telephone sets, including telephones for cellular } \\
\text { networks or for other wireless networks; other } \\
\text { apparatus for the transmission or reception of voice, } \\
\text { images or other data }\end{array}$ & 3059444.063 & $2.04 \%$ & $1.15 \%$ & 1.79 \\
\hline 9 & Vietnam & 1006 & Rice & 2936931.047 & $1.96 \%$ & $0.13 \%$ & 14.56 \\
\hline 10 & Vietnam & 6204 & $\begin{array}{l}\text { Coats; women's or girls' overcoats, car coats, capes, } \\
\text { cloaks, anoraks, ski-jackets, wind-cheaters, wind- } \\
\text { jackets and similar articles }\end{array}$ & 2766755.364 & $1.85 \%$ & $0.33 \%$ & 5.63 \\
\hline 11 & Vietnam & 8544 & $\begin{array}{l}\text { Insulated wire, cable and other electric conductors, } \\
\text { connector fitted or not; optical fibre cables of } \\
\text { individually sheathed fibres, whether or not } \\
\text { assembled with electric conductors or fitted with } \\
\text { connectors }\end{array}$ & 2719062.151 & $1.82 \%$ & $0.66 \%$ & 2.76 \\
\hline 12 & Vietnam & 306 & $\begin{array}{l}\text { Crustaceans; in shell or not, live, fresh, chilled, } \\
\text { frozen, dried, salted or in brine; smoked, cooked or } \\
\text { not before or during smoking; in shell, steamed or } \\
\text { boiled, whether or not chilled, frozen, dried, salted } \\
\text { or in brine; edible flours, meals, pellets }\end{array}$ & 2553754.261 & $1.71 \%$ & $0.14 \%$ & 12.22 \\
\hline 13 & Vietnam & 6203 & $\begin{array}{l}\text { Suits, ensembles, jackets, blazers, trousers, bib and } \\
\text { brace overalls, breeches and shorts }\end{array}$ & 2452843.803 & $1.64 \%$ & $0.23 \%$ & 7.00 \\
\hline 14 & Vietnam & 304 & $\begin{array}{l}\text { Fish fillets and other fish meat (whether or not } \\
\text { minced); fresh, chilled or frozen }\end{array}$ & 2415085.853 & $1.61 \%$ & $0.11 \%$ & 14.18 \\
\hline 15 & Vietnam & 6110 & $\begin{array}{l}\text { Jerseys, pullovers, cardigans, waistcoats and similar } \\
\text { articles; knitted or crocheted }\end{array}$ & 2337234.8 & $1.56 \%$ & $0.24 \%$ & 6.38 \\
\hline & Total & & & & $47.45 \%$ & $14.88 \%$ & \\
\hline & Average & & & & & & 8.33 \\
\hline
\end{tabular}


ANNEX D

Table 3-5: Average FDI Regulatory Restrictiveness Index of the EU member states (2010-2015)

\begin{tabular}{|c|l|c|c|l|c|}
\hline No & \multicolumn{1}{|c|}{ Country } & $\begin{array}{c}\text { Average FRRI } \\
\mathbf{( 2 0 1 0 - 2 0 1 5 )}\end{array}$ & No & Country & $\begin{array}{c}\text { Average FRRI } \\
\mathbf{( 2 0 1 0 - 2 0 1 5 )}\end{array}$ \\
\hline 1 & Austria & 0.106 & 13 & Latvia & 0.029 \\
\hline 2 & Belgium & 0.04 & 14 & Lithuania & 0.035 \\
\hline 3 & Czech Republic & 0.01 & 15 & Luxembourg & 0.004 \\
\hline 4 & Denmark & 0.033 & 16 & Netherlands & 0.015 \\
\hline 5 & Estonia & 0.02 & 17 & Poland & 0.072 \\
\hline 6 & Finland & 0.019 & 18 & Portugal & 0.007 \\
\hline 7 & France & 0.045 & 19 & Slovak Republic & 0.049 \\
\hline 8 & Germany & 0.023 & 20 & Slovenia & 0.007 \\
\hline 9 & Greece & 0.032 & 21 & Spain & 0.021 \\
\hline 10 & Hungary & 0.029 & 22 & Sweden & 0.059 \\
\hline 11 & Ireland & 0.043 & 23 & United Kingdom & 0.061 \\
\hline 12 & Italy & 0.052 & 24 & EU Average & 0.035 \\
\hline
\end{tabular}

Source: OECD Statistics 